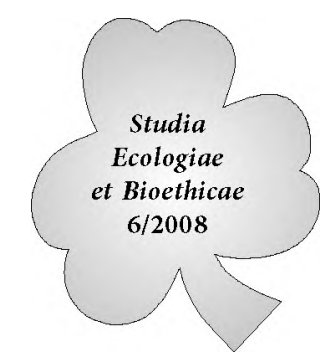

\title{
Osobowość ekologiczna płci - badania ankietowe
}

\section{Wstęp}

W 1997 roku Synod Biskupów w dwadzieścia lat po Soborze Watykańskim II wskazywał na konieczność pogłębiania podstaw antropologicznych i teologicznych potrzebnych do rozwiązania problemów odnoszących się do znaczenia i godności bycia kobietą i bycia mężczyzną. Chodziło o zrozumienie przyczyn i skutków postanowienia Stwórcy, aby istota ludzka bytowała zawsze i jedynie jako kobieta i jako mężczyzna.

Współczesne tendencje często anulują różnice płci w procesie wychowania, co nie przynosi dobrych rezultatów. Papieskie dokumenty uzmysławiają, że warto na nowo odkryć, że różnice biologiczne, kulturowe, osobowe i duchowe między kobietą i mężczyzną, są bogactwem, z którego można sensownie korzystać w procesie dojrzewania do relacji między kobietą i mężczyzną.

Dzisiejsze czasy obfitują w opinię o zaniku ojcostwa, o braku zainteresowania związkami i są oparte na źródłach kulturowych, w konsekwencji doprowadzają do coraz większej płciowej obcości. Ważne jest też pamiętanie o tym, że przyjmowanie nie swoich ról powoduje dezorientacje i jest destrukcyjne. Umiejętność wzbogacania się pod wpływem drugiej osoby nie oznacza utraty własnej natury i osobowości.

Jeśli zadamy pytanie, czy mężczyźni i kobiety są tacy sami, czy różni?, to najprawdopodobniej odpowiedzią będzie stwierdzenie - są tacy sami i różni. Jesteśmy tacy sami, bo pochodzimy z tego samego ciała i dzielimy taką samą naturę, ale jednocześnie jesteśmy różni, bo jesteśmy kobietą lub mężczyzną.

Znaczącym głosem w sprawy jedności i dwoistości mężczyzny i kobiety był list apostolski Mulieris dignitatem Jana Pawła II ogłoszony 15 sierpnia 1988 r., mówiący o powołaniu i godności kobiety, bogaty w treści teologiczne, duchowe i kulturowe. W tym liście Jan Paweł II zgłębił fundamentalne prawdy antropologiczne o mężczyźnie i kobiecie, poruszył kwestię ich równości w godności, jedności, ale również głęboko tkwiącej różnicy między męskością a kobiecością, a także ich powołania do wzajemności i komplementarności. 
Benedykt XVI ${ }^{1}$ na podstawie listu Mulieris dignitatem przestrzega przed unikaniem zarówno schematycznego ujednolicania i spłaszczającej, zubożającej równości, jak i zasadniczego zróżnicowania, które prowadziłoby nieuchronnie do konfliktu. Wielka chęć niezależności i samowystarczalności zarówno kobiet jak i mężczyzn zagraża skupieniem się na samorealizacji i źle rozumianej wolności, a to z kolei skutkuje nieznośną wręcz samotnością.

Ogromną potrzebą i wyzwaniem stają się badania antropologiczne oparte na tradycji chrześcijańskiej, rzetelnej nauce i kulturze. Niezależnie od panujących ideologii, poglądów i kultury należy pamiętać o zamyśle Boga, który stworzył człowieka mężczyzną i kobietą, od początku obdarzył ich jednością i dopełniającym się zróżnicowaniem. Posiadając wiedzę o dwoistości natury ludzkiej w mężczyźnie i kobiecie, możemy ją stosować w praktyce, licząc się z ich przyrodzonymi predyspozycjami i potencjalnością, aby lepiej służyć innym w tych specyficznych, swoistych rolach.

Edyta Stein kieruje uwagę na dwie bardzo ważne różnice między mężczyzną i kobietą, które często są wymieniane i znane, ale ważność tego zagadnienia zasadza się na tym, że podstawą do przemiany świadomości samych kobiet i mężczyzn w ich poznaniu płciowym jest przyjęcie kobiecej swoistości jako faktu oczywistego. Samoświadomość kobieca może również budzić przekonanie, że w swoistości zawiera się wartość własna. Dlatego tak bardzo ważne jest wskazanie na podstawowe różnice.

Mężczyzna swoje siły koncentruje kierując się ku rzeczom, natomiast nastawienie kobiety jest bardziej osobiste, całą swoją osobą angażuje się we wszystko, co czyni. Kobieta nie potrafi rozdzielić np. spraw zawodowych, biurowych od żywego zainteresowania własnym życiem osobistym, jak też innych wokół.

Umiejętność koncentracji na konkretnych rzeczach pozwala mężczyźnie doświadczyć jednostronnego rozwoju, a kobietę kieruje na dążenie ku całości i zwartości, a to znowu w podwójnym kierunku. Kobieta sama chciałaby rozwijać się w pełni i wielostronnie, ale również chciałaby innym dopomóc $w$ takim rozwoju. \e różnice są znaczące w realizowaniu macierzyństwa i ojcostwa, w spełnianiu podstawowych ról w rodzinie, społeczeństwie i szeroko pojętym funkcjonowaniu w środowisku, dlatego muszą być świadomie przyjęte, aby mogły być ubogaceniem w związku i wzajemnych relacjach.

\section{Wynki badań}

Biorąc pod uwagę zróżnicowanie płciowe przeprowadziłam badania ankietowe, które miały potwierdzić różnice w kształtowaniu osobowości ekologicznej, różne podejście do spraw związanych z kształtowaniem i ochroną środowiska.

Benedykt XVI do uczestników kongresu z okazji 20-lecia Listu apostolskiego Mulieris dignitatem w LOSSERVA囚ORE ROMANO nr 4 (302), 2008, s. 20-21. 
Moje badania ankietowe dotyczyly sfery emocjonalnej i socjalnej, a miały na celu ustalić pewne cechy osobowości, które charakteryzują postawę prośrodowiskową i prospołeczną. Model człowieka przetrwania przedstawiłam w mojej rozprawie doktorskiej, natomiast część danych, które otrzymałam podczas tych badań, dopiero teraz wykorzystam do dalszych moich rozważań, dotyczących roli kobiety i mężczyzny w kształtowaniu dojrzałej osobowości człowieka przetrwania.

Jedną z danych metryczkowych była płeć i właśnie ten czynnik poddałam analizie. Sporządziłam nowe wykresy i na ich podstawie wyciągnęlam wnioski, dotyczące różnic w postrzeganiu środowiska między dziewczętami a chłopcami w przedziale wiekowym między 16 a 19 rokiem życia.

W modelu regresyjnym opisującym determinanty wartości realizowanych, który opracowałam na potrzeby pracy doktorskiej, wpływ płci nie miał istotnego znaczenia ${ }^{2}$. Natomiast analiza odpowiedzi prześledzona tylko ze względu na rozróżnienie na płeć przyniosła potwierdzenie stawianych przeze mnie tez:

- Bardziej całościowe spojrzenie na środowisko charakteryzuje dziewczyny

- Przy podejmowaniu decyzji dziewczęta są skłonne rozważać wieloaspektowo i w zależności od sytuacji

- Dziewczęta bardziej radykalnie wiążą środowisko z ochroną życia człowieka

- Wprowadzanie zasad głębokiego człowieczeństwa, opartego nie tylko na umiejętności współżycia z innymi, ale przede wszystkim bycia dla drugiego bardziej charakteryzuje kobiety

- Chłopcy koncentrują bardziej swoją uwagę na konkretnych rozwiązaniach technologicznych i zrealizowaniu postawionego celu.

\section{DANE ME囚RYCZKOWE}

\begin{tabular}{|l|r|r|}
\hline OGÓŁEM: & \multicolumn{1}{c|}{$\mathrm{N}$} & \multicolumn{1}{c|}{$\%$} \\
PŁEĆ & 849 & $\mathbf{1 0 0 \%}$ \\
chłopak & 359 & $42.3 \%$ \\
dziewczyna & 489 & $57.6 \%$ \\
brak danych & 1 & $.1 \%$ \\
MIEJSCOWOŚC & & \\
\hline miasto & 489 & $57.6 \%$ \\
wieś & 309 & $36.4 \%$ \\
brak danych & 51 & $6.0 \%$
\end{tabular}

2 Model regresyjny opisujący determinanty wartości realizowanych, w: I. Grochowska, Ekofilozoficzne uwarunkowania integralnego rozwoju człowieka w ocenie młodzieży, rozprawa doktorska napisana na Wydziale Filozofii Chrześcijańskiej UKSW, 2004, s. 212. 


\begin{tabular}{|c|c|c|}
\hline MIEJSCE ZAI & & \multirow{5}{*}{$\begin{array}{r}66.2 \% \\
24.5 \% \\
9.3 \%\end{array}$} \\
\hline dom & 562 & \\
\hline mieszkanie & 208 & \\
\hline brak danych & 79 & \\
\hline \multicolumn{2}{|l|}{ KLASA } & \\
\hline $1 . \mathrm{kl}$ & 234 & $27.6 \%$ \\
\hline $2 . \mathrm{kl}$ & 354 & $41.7 \%$ \\
\hline $3 . \mathrm{kl}$ & 231 & $27.2 \%$ \\
\hline $4 . \mathrm{kl}$ & 22 & $2.6 \%$ \\
\hline brak danych & 8 & $.9 \%$ \\
\hline \multicolumn{3}{|c|}{ WARUNKI MA®ERIALNE } \\
\hline dobre & 533 & $62.8 \%$ \\
\hline średnie & 290 & $34.2 \%$ \\
\hline złe & 16 & $1.9 \%$ \\
\hline brak danych & 10 & $1.2 \%$ \\
\hline \multicolumn{3}{|c|}{ WYKSZХAŁCENIE OJCA } \\
\hline podstawowe & 48 & $5.7 \%$ \\
\hline średnie & 461 & $54.3 \%$ \\
\hline wyższe & 314 & $37.0 \%$ \\
\hline brak danych & 26 & $3.1 \%$ \\
\hline \multicolumn{3}{|c|}{ WYKSZХAŁCENIE MA囚KI } \\
\hline podstawowe & 21 & $2.5 \%$ \\
\hline średnie & 469 & $55.2 \%$ \\
\hline wyższe & 340 & $40.0 \%$ \\
\hline brak danych & 19 & $2.2 \%$ \\
\hline
\end{tabular}

\section{ZAIN囚ERESOWANIA}

\begin{tabular}{|c|c|c|c|c|c|c|c|c|c|c|}
\hline & $\begin{array}{l}\overrightarrow{5} \\
\text { के }\end{array}$ & 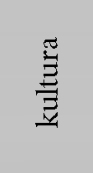 & 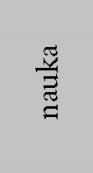 & $\begin{array}{l}\frac{\pi}{60} \\
\frac{0}{0} \\
\frac{8}{2}\end{array}$ & 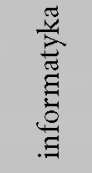 & $\begin{array}{l}\frac{\pi}{\mathbb{a}} \\
\frac{\pi}{2} \\
\frac{3}{0} \\
0 \\
\vdots\end{array}$ & 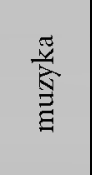 & $\stackrel{\Xi}{\Xi}$ & $\widehat{\hat{\theta}}$ & 岕 \\
\hline OGÓLEM & $50.1 \%$ & $33.0 \%$ & $13.2 \%$ & $6.8 \%$ & $19.7 \%$ & $5.7 \%$ & $47.8 \%$ & $1.9 \%$ & $99.8 \%$ & 849 \\
\hline \multicolumn{11}{|l|}{ P£EĆ } \\
\hline chłopak & $54.3 \%$ & $21.4 \%$ & $9.7 \%$ & $4.5 \%$ & $41.5 \%$ & $12.5 \%$ & $29.5 \%$ & $1.7 \%$ & $100 \%$ & 359 \\
\hline dziewczyna & $46.8 \%$ & $41.3 \%$ & $15.5 \%$ & $8.6 \%$ & $3.7 \%$ & $.6 \%$ & $61.3 \%$ & $2.0 \%$ & $99.6 \%$ & 489 \\
\hline
\end{tabular}




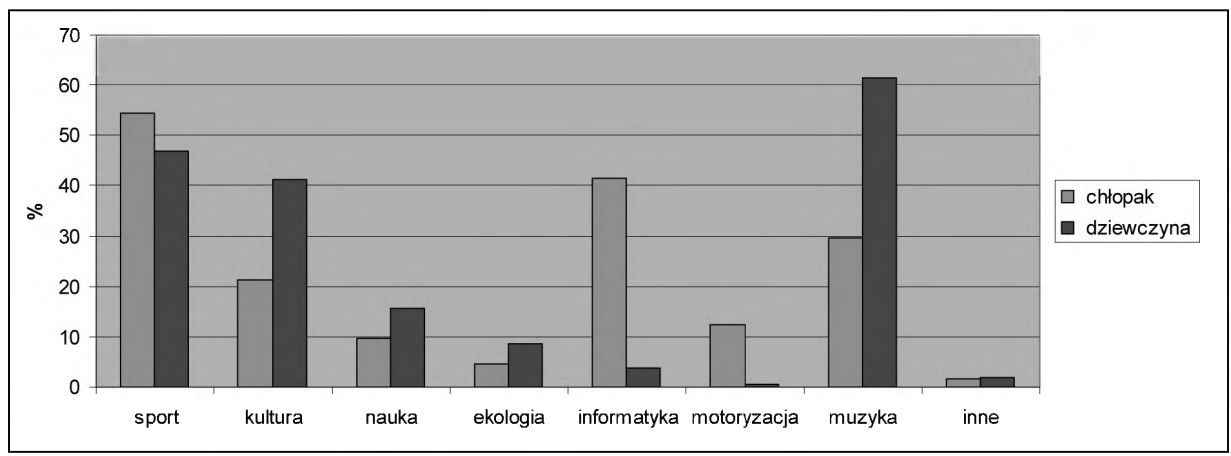

Wyraźnie widać zróżnicowanie w zainteresowaniach. Chłopcy preferują sport, informatykę i motoryzację. Dziewczyny dominują w takich zainteresowaniach jak szeroko pojęta kultura, nauka, problemy ekologii i muzyka. W granicach $30 \%$ zainteresowań, które dotyczą obu płci można wyróżnić sport i muzykę. Wygląda na to, że te dwie dziedziny najbardziej jednoczą obie płcie w zainteresowaniach. Przy dzisiejszym stanie wiedzy nie dyskutujemy na temat, czy kobieta różni się od mężczyzny, bo wiemy, że tak, ale szukamy potwierdzenia przyczyn tej różności płci w badaniach naukowych. Wiemy dużo o różnicy w budowie mózgów obu $\mathrm{płci}^{3}$. 『a wiedza, którą posiadamy, pozwala wyjaśnić przyczynę rozbieżności w zainteresowaniach.

\section{NIECHĘĆ WOBEC PRZEKSZTALCEŃ ŚRODOWISKA}

Czy chciałbyś, aby środowisko przyrodnicze nie ulegało tak szybkim przekształceniom?

\begin{tabular}{|c|c|c|c|c|c|c|c|}
\hline \#A01 & $x^{2}$ & Istotność & $\nabla \mathrm{ak}$ & $\mathrm{Nie}$ & $\begin{array}{l}\text { Drudno } \\
\text { powie- } \\
\text { dzieć }\end{array}$ & (BD) & LICZBA \\
\hline OGÓŁEM & & & $68.2 \%$ & $8.7 \%$ & $22.0 \%$ & $1.1 \%$ & 849 \\
\hline PŁEĆ & 12.25658 & 0.00218 & & & & & \\
\hline chłopak & & & $62.7 \%$ & $12.3 \%$ & $23.7 \%$ & $1.4 \%$ & 359 \\
\hline dziewczyna & & & $72.2 \%$ & $6.1 \%$ & $20.9 \%$ & $.8 \%$ & 489 \\
\hline
\end{tabular}

Czajkowska D. Nowy Lepszy? CZŁowiek, 2005, Warszawa, Wydawnictwo Akademickie „Żak”, s. 145 - 153, L. Brizendine, Mózg kobiety, 2006, Gdańsk, VM GROUP, Mózg a zachowanie, (red.) \. Górska, A. Grabowska, J. Zagrodzka, 2006, Warszawa, PWN. 


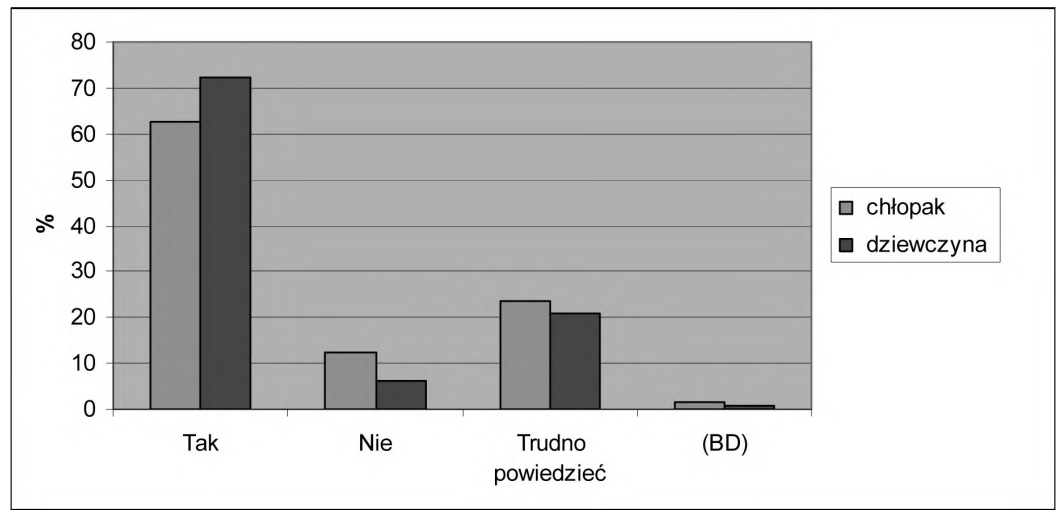

Jeśli chodzi o przekształcanie środowiska, to chłopcy są mniej zachowawczy, większy procent ich odpowiedzi oznacza, że chętniej godzą się na zmiany. Dziewczęta aż w $72,2 \%$ są przeciwne szybkim zmianom w środowisku, chłopcy w $62,7 \%$. Warto też zwrócić uwagę na większy procent niezdecydowanych wśród chłopców.

Z tych wykresów widać, że chłopcy mają mniej oporów, co do przekształcania przyrody. Jeżeli mają pomysły, coś lubią, to chcą to zrealizować. U dziewcząt widać tutaj pewną zachowawczość w konkretnym działaniu, są mniej chętne do zmian, nie chcą burzyć czegoś, co spełnia swoją rolę. Można by tutaj wskazać na dążenie dziewcząt do pewnego konformizmu między naturą a aktywnością człowieka, na dążenie do integracji, do zachowania całości.

\section{BUDOWA DOMU Z TROSKĄ O PRZYRODĘ}

Gdybyś budował dom, to czy będziesz myślał o tym, żeby w jak najmniejszym stopniu zniszczyć przyrodę, nawet kosztem większego wysiłku?

\begin{tabular}{|c|c|c|c|c|c|c|c|c|c|}
\hline \#A02 & $\mathscr{x}$ & 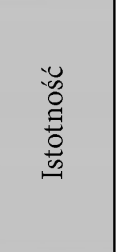 & 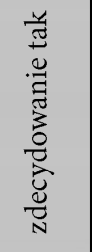 & 苛 & 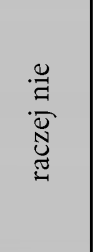 & 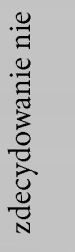 & 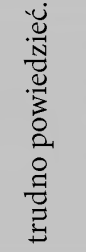 & $\widehat{\hat{\theta}}$ & 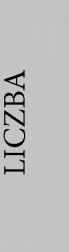 \\
\hline OGÓEEM & & & $16.6 \%$ & $47.8 \%$ & $16.4 \%$ & $2.8 \%$ & $16.1 \%$ & $.2 \%$ & 849 \\
\hline PŁEĆ & 28.83568 & 0.00001 & & & & & & & \\
\hline chłopak & & & $13.6 \%$ & $42.6 \%$ & $19.2 \%$ & $5.6 \%$ & $18.4 \%$ & $.6 \%$ & 359 \\
\hline dziewczyna & & & $18.6 \%$ & $51.7 \%$ & $14.3 \%$ & $.8 \%$ & $14.5 \%$ & $.0 \%$ & 489 \\
\hline
\end{tabular}




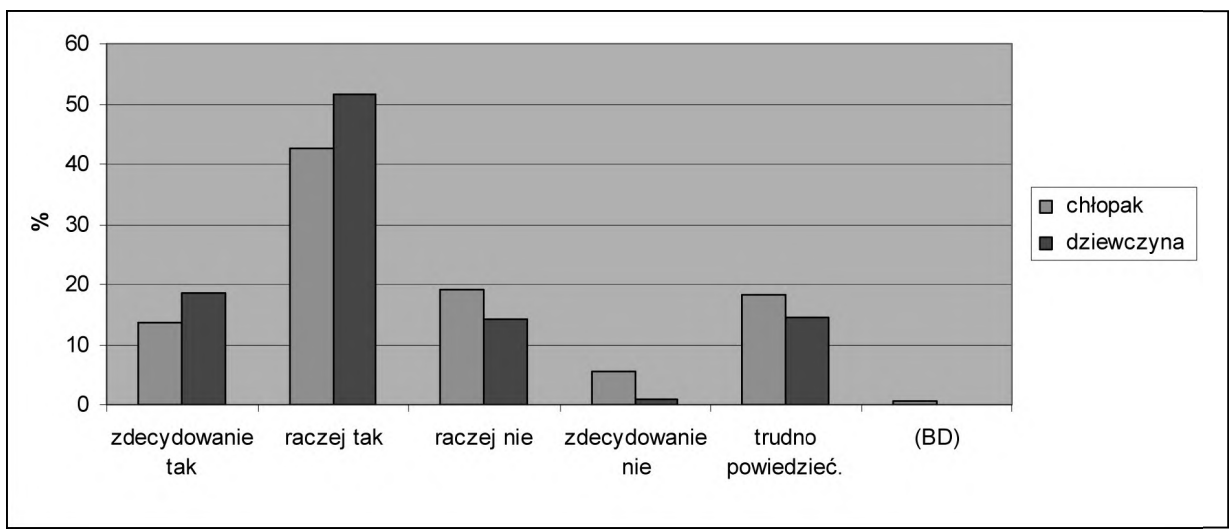

W pytaniu o troskę o środowisko przy okazji innych okoliczności jak np. budowa domu, dziewczęta zdecydowanie opowiadają się za takimi rozwiązaniami, które mniej ingerują w środowisko. Chłopcy w mniejszym procencie chcą łączyć te dwie rzeczy tj. ochronę środowiska i budowę domu. W podziale typów osobowości, chłopcy dominowali w osobowości technokraty, konsumpcjonisty i racjonalisty.

\section{WAŻNOŚĆ KONTAKTU Z PRZYRODĄ}

Czy w twoim codziennym życiu ważny jest dla ciebie kontakt z przyrodą?

\begin{tabular}{|c|c|c|c|c|c|c|c|c|c|}
\hline \#A03 & 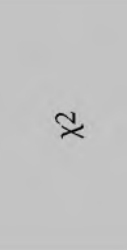 & 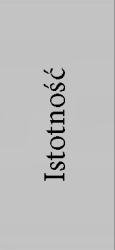 & 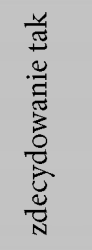 & 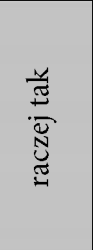 & 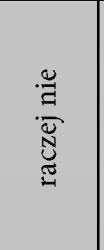 & 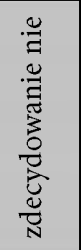 & 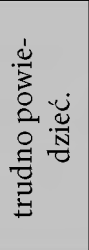 & $\widehat{\hat{\theta}}$ & 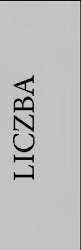 \\
\hline OGÓŁEM & & & $34.2 \%$ & $47.7 \%$ & $10.4 \%$ & $1.4 \%$ & $6.2 \%$ & $.1 \%$ & 849 \\
\hline PEEĆ & 69.48826 & 0.00000 & & & & & & & \\
\hline chłopak & & & $22.6 \%$ & $48.7 \%$ & $16.7 \%$ & $3.1 \%$ & $8.9 \%$ & $.0 \%$ & 359 \\
\hline dziewczyna & & & & & & $.2 \%$ & $4.3 \%$ & $.2 \%$ & 489 \\
\hline
\end{tabular}




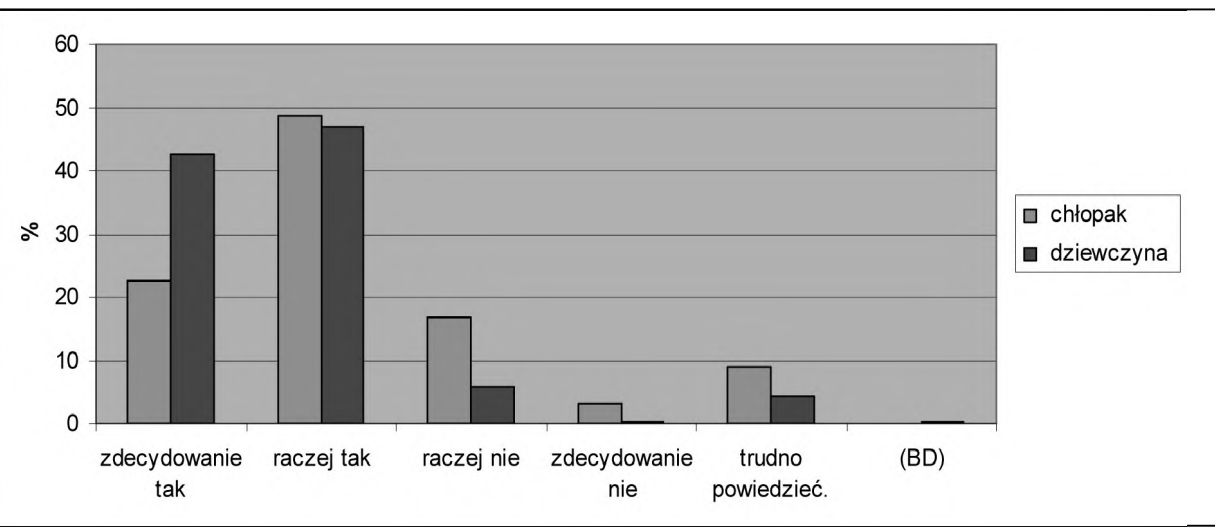

Kontakt z przyrodą jest zdecydowanie ważniejszy dla dziewcząt, nawet do tego stopnia, że tylko $2 \%$ opowiada się, że nie jest im potrzebny ten kontakt. Chłopcy natomiast jak widać $\mathrm{z}$ wykresu zdecydowanie w mniejszym stopniu opowiadają się za koniecznością kontaktu z przyrodą. Ale należy zwrócić uwagę na to, że duży procent chłopców charakteryzują mniej wyraźnie odpowiedzi np. „raczej tak” i w tym przypadku chłopcy nieznacznie przewyższyli dziewczęta, z czego można wnioskować, że chłopcom środowisko jest również potrzebne, chociaż nie opowiedzieli się za tym zdecydowanie. Chłopcy na środowisko patrzą bardziej jak na magazyn części, które można racjonalnie wykorzystać. Stąd pewnie wynikają te różnice, a nie $z$ ignorancji środowiska przyrodniczego przez chłopców.

O jakości swojego życia w zależności od środowiska zdecydowanie bardziej przekonane są młode kobiety niż mężczyźni. Kobiety wręcz dostrzegają prostą i oczywistą zależność między jakością życia a jakością środowiska. Dziewczęta w środowisku upatrują bezpieczeństwa, szukają "domu życia”. Harmonia w środowisku stanowi dla nich wprost ochronę życia człowieka. Mniejsze zaufanie pokładają w mądrości i samowystarczalności człowieka niż chłopcy.

\section{ZACHWYT NAD PRZYRODA}

\section{Czy przyroda wywołuje u Ciebie zachwyt?}

\begin{tabular}{|c|c|c|c|c|c|c|c|c|c|}
\hline \#A05 & $\underset{x}{x}$ & 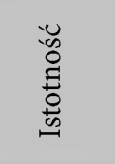 & 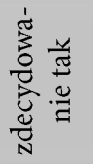 & 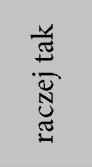 & 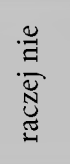 & 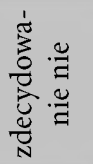 & 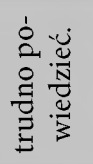 & $\widehat{\hat{\theta}}$ & 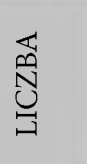 \\
\hline OGÓŁEM & & & $56.2 \%$ & $34.3 \%$ & $4.2 \%$ & $1.1 \%$ & $3.9 \%$ & $.4 \%$ & 849 \\
\hline PŁEĆ & 90.55572 & 0.00000 & & & & & & & \\
\hline chłopak & & & $39.8 \%$ & $42.6 \%$ & $8.1 \%$ & $2.5 \%$ & $6.4 \%$ & $.6 \%$ & 359 \\
\hline dziewczyna & & & $68.1 \%$ & $28.2 \%$ & $1.4 \%$ & $.0 \%$ & $2.0 \%$ & $.2 \%$ & 489 \\
\hline
\end{tabular}




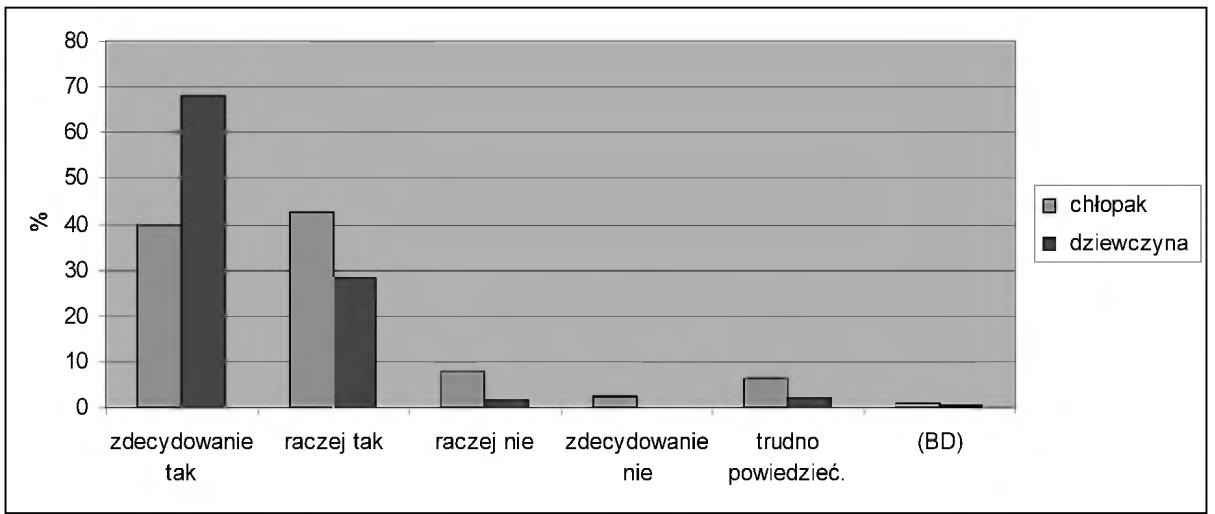

Zdecydowany zachwyt nad przyrodą wyrazily dziewczęta, ale jeżeli prześledzić dwa pierwsze wykresy, które są odpowiedzią potwierdzającą,(różnicuje je tylko prawdopodobnie wymiar emocjonalny) stąd możemy wyciągnąć wniosek, że chłopcy również doceniają piękno przyrody, ale są bardziej zachowawczy i mniej ekspresyjni w okazywaniu swoich uczuć w stosunku do przyrody.

Dziewczęta traktują przyrodę jako część ich życia i wartość samą w sobie. Dla dziewcząt mocniej przyroda kojarzy się z ochroną życia człowieka w ogóle. Chłopcy odważniej opowiadają się za praktycznymi walorami przyrody, stąd widzą w środowisku materiał, który można lepiej wykorzystać, aby żyło się „lepiej” i wygodniej.

RESP. JAKO DYREKTOR FABRYKI - WAŻNOŚĆ

Gdybyś był dyrektorem dużej fabryki tworzyw sztucznych, co byłoby dla ciebie ważne? Zakreśl odpowiedzi, umieszczając je na wykresie według ważności.

1. mało ważne

6. bardzo ważne. 


\begin{tabular}{|c|c|c|c|c|}
\hline 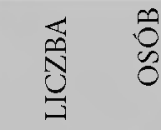 & $\frac{\Omega}{\infty}$ & & 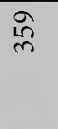 & $\stackrel{\infty}{\infty}$ \\
\hline 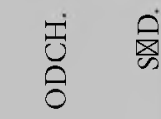 & $\stackrel{\circ}{-}$ & & $\stackrel{0}{-}$ & 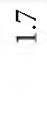 \\
\hline b. & $\vec{n}$ & & $\begin{array}{l}\infty \\
\dot{n}\end{array}$ & $?$ \\
\hline$\stackrel{\Perp}{\Xi}$ & & \begin{tabular}{l}
1 \\
\multirow{8}{8}{} \\
0 \\
0
\end{tabular} & & \\
\hline$=$ & & $\begin{array}{l}1 \\
0 \\
0 \\
0 \\
0\end{array}$ & & \\
\hline$\stackrel{\Xi}{\Xi} \quad$ 离 & $\stackrel{+}{-}$ & & $\stackrel{4 n}{9}$ & $\stackrel{?}{\sim}$ \\
\hline 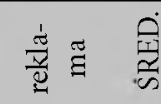 & $\begin{array}{l}0 \\
i\end{array}$ & & $\stackrel{\rho}{\dot{r}}$ & $\stackrel{m}{\sim}$ \\
\hline$\cong$ & & $\begin{array}{l}\stackrel{L}{\infty} \\
\stackrel{0}{0} \\
0 \\
0\end{array}$ & & \\
\hline$=$ & & 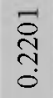 & & \\
\hline$\stackrel{\ominus}{\circlearrowright} \quad$ 希 & $\stackrel{\infty}{-}$ & & $\stackrel{\infty}{-}$ & $\stackrel{\infty}{-}$ \\
\hline 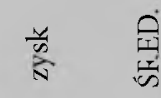 & $\begin{array}{l}\infty \\
\dot{r}\end{array}$ & & $\stackrel{\Upsilon}{+}$ & $\frac{m}{n}$ \\
\hline 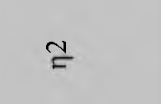 & & ت & & \\
\hline$=$ & & ָे & & \\
\hline \# & $\begin{array}{l}\sum_{1} \\
0 \\
0 \\
0 \\
0\end{array}$ & 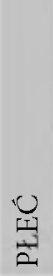 & 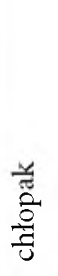 & 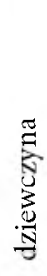 \\
\hline
\end{tabular}

\begin{tabular}{|c|c|c|c|c|}
\hline 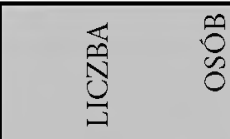 & $\stackrel{\sigma}{\infty}$ & & in & के \\
\hline 焉 & $\cong$ & & 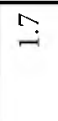 & $\stackrel{0}{-}$ \\
\hline 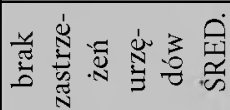 & $\ddot{m}$ & & $\vec{r}$ & in \\
\hline$\stackrel{\mathcal{L}}{=}$ & & 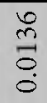 & & \\
\hline$=$ & & $\begin{array}{l}\mathscr{8} \\
ٍ \\
0\end{array}$ & & \\
\hline 焉 & $\cong$ & & 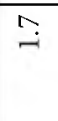 & $\stackrel{0}{-}$ \\
\hline 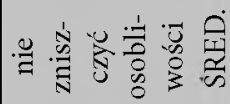 & $\hat{r}$ & & $\stackrel{H}{\dot{r}}$ & $\stackrel{\circ}{\circ}$ \\
\hline$\cong$ & & $\begin{array}{l}1 \\
\stackrel{N}{2} \\
0 \\
0\end{array}$ & & \\
\hline$=$ & & $\begin{array}{l}0 \\
1 \\
\infty \\
0\end{array}$ & & \\
\hline 蒠 & 욤 & & $\cong$ & $\stackrel{0}{-}$ \\
\hline 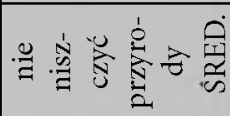 & $\dot{m}$ & & in & $\stackrel{\sim}{\sim}$ \\
\hline$\cong$ & & $\begin{array}{l}R \\
0 \\
0 \\
0\end{array}$ & & \\
\hline$=$ & & $\frac{\vec{N}}{0}$ & & \\
\hline 邦 & 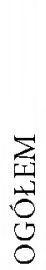 & 峲 & $\begin{array}{l}\frac{y}{\tilde{I}} \\
\frac{0}{0} \\
\frac{0}{3}\end{array}$ & 莺 \\
\hline
\end{tabular}




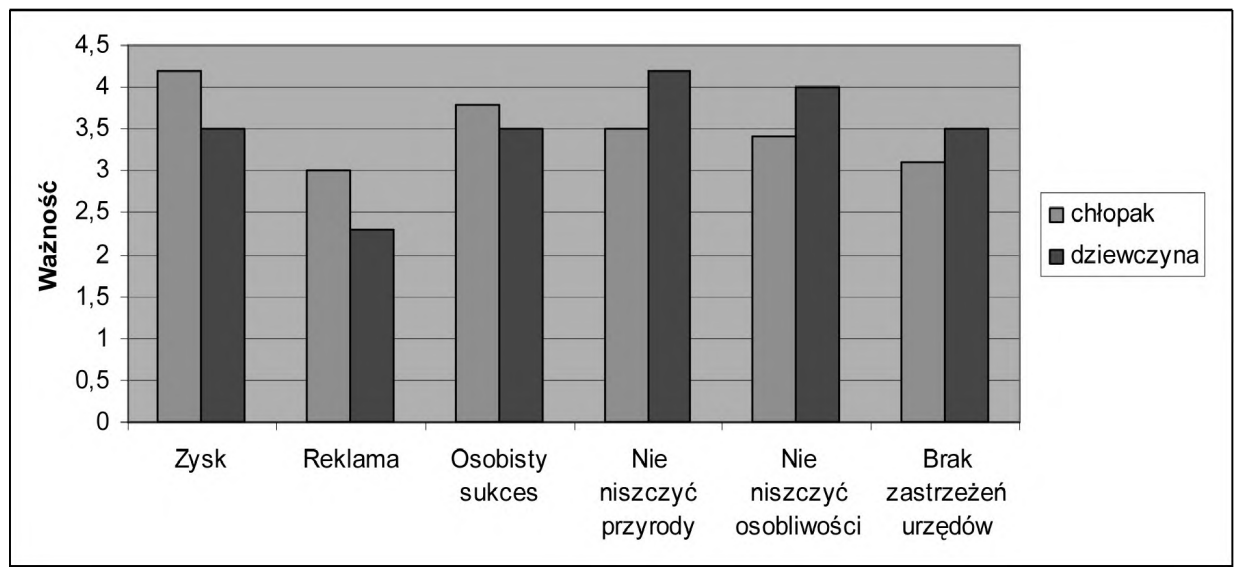

Wyraźne zróżnicowanie. Chłopcy zwrócili uwagę na rzeczy związane z konkretnymi zyskami fabryki, którą mają zarządzać. Dla dziewcząt ważniejsze były inne sprawy, aby nie zaszkodzić, nie popsuć całości, którą razem z nami tworzy przyroda. Dziewczęta też zatroszczyły się o sytuacje bezkonfliktowe. Relacje, więzi jak wiemy są dla dziewcząt i kobiet bardzo ważne i tutaj w tym przypadku zostało to potwierdzone.

W tych odpowiedziach nieznacznie zarysowują się różnice, ale można odczytać z nich i potwierdzić cechy charakteryzujące kobiety i mężczyzn. Dziewczęta wybierają rozwiązanie mniej zakłócające zaistniały porządek. Chłopcy wyraźniej opowiadają się za tym, co wolą, co jest dla nich wygodniejsze i w tym konkretnym przypadku, środowisko schodzi na dalszy plan, nie jest celem w tych konkretnych wyborach.

\section{PRZYRODA JAKO WSPÓLNE DOBRO}

\section{Czy przyroda jest naszym dobrem wspólnym?}

\begin{tabular}{|c|c|c|c|c|c|c|c|c|c|}
\hline$\varlimsup_{\sharp}^{Z}$ & $\approx$ & 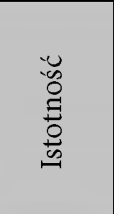 & 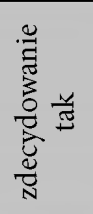 & 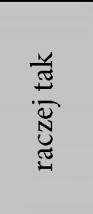 & 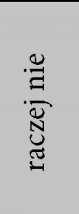 & 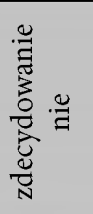 & 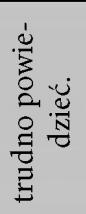 & 周 & 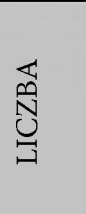 \\
\hline OGÓŁEM & & & $66.0 \%$ & $25.4 \%$ & $3.2 \%$ & $.9 \%$ & $3.7 \%$ & $.8 \%$ & 849 \\
\hline PŁEĆ & 11.43979 & 0.02204 & & & & & & & \\
\hline chłopak & & & $61.8 \%$ & $26.7 \%$ & $4.2 \%$ & $1.9 \%$ & $4.2 \%$ & $1.1 \%$ & 359 \\
\hline dziewczyna & & & $68.9 \%$ & $24.5 \%$ & $2.5 \%$ & $.2 \%$ & $3.3 \%$ & $.6 \%$ & 489 \\
\hline
\end{tabular}




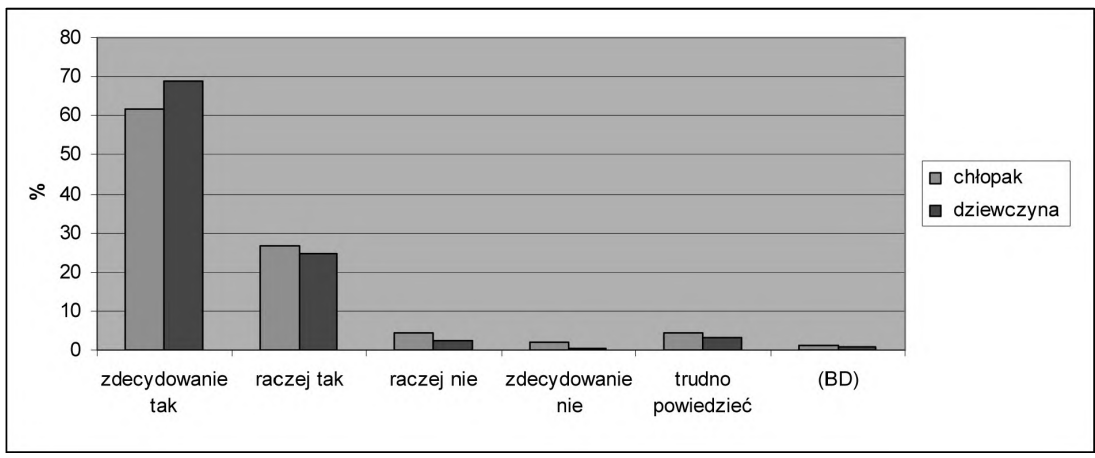

Wspólnotowy wymiar życia i w związku z tym dobro wspólne wyraźniej respektują dziewczyny. Wśród chłopców przeważają odpowiedzi ujawniające ich wątpliwości, co do tej zasady. W charakterystyce mężczyzn i chłopców często zwraca się uwagę na ich oddzielenie i samodzielność, można więc wnioskować, że takie odpowiedzi są rezultatem wpływu wychowania i kultury, ale także ich przyrodzonych cech.

\section{GROŹBA PRZELUDNIENIA}

\section{Czy Twoim zdaniem grozi światu przeludnienie?}

\begin{tabular}{|l|r|r|r|r|r|r|r|}
\hline \multicolumn{1}{|c|}{ \#B01 } & \multicolumn{1}{c|}{$\chi^{2}$} & Istotność & tak & nie & $\begin{array}{r}\text { nie mam } \\
\text { zdania. }\end{array}$ & \multicolumn{1}{c|}{ (BD) } & \multicolumn{1}{c|}{ LICZBA } \\
\hline OGÓ£EM & & & $52.8 \%$ & $25.6 \%$ & $21.0 \%$ & $.8 \%$ & 849 \\
\hline PŁEĆ & 49.32348 & 0.00000 & & & & & \\
chłopak & & & $65.7 \%$ & $20.9 \%$ & $12.3 \%$ & $1.2 \%$ & 359 \\
dziewczyna & & & $43.1 \%$ & $29.0 \%$ & $27.4 \%$ & $.4 \%$ & 489 \\
\hline
\end{tabular}

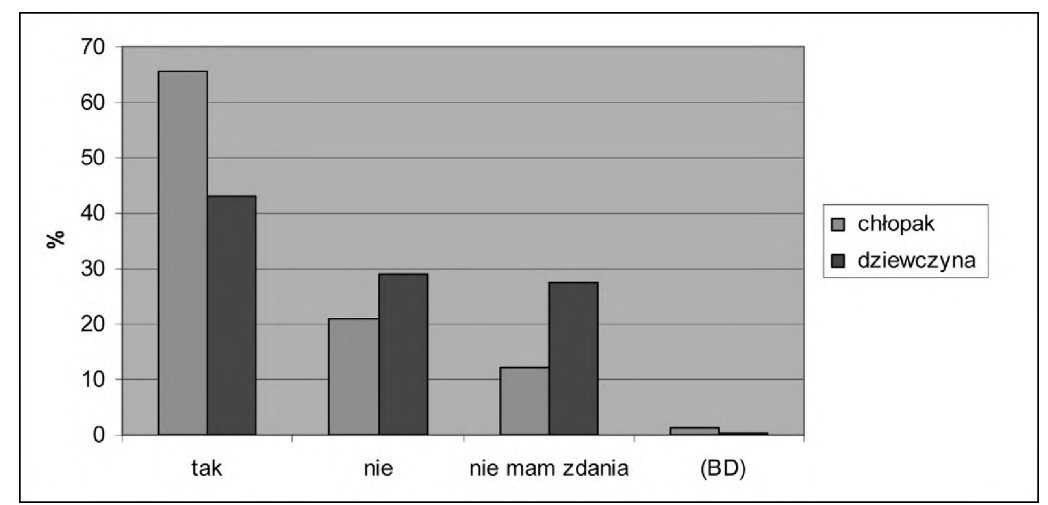


Odpowiedzi na to pytanie wyraźnie są zróżnicowane, chłopcy zdecydowanie $(65,7 \%)$ deklarują zagrożenie przeludnieniem, dziewczęta odwrotnie, w większym procencie nie popierają tej opinii. Równie ciekawa jest odpowiedz trzecia, w której wyraźnie dominują dziewczęta, przyznając się, że nie mają zdania na ten temat. Brak zdania u dziewcząt można wytłumaczyć mniejszym zainteresowaniem i mniejszą wiedzą na tematy dotyczące przemian społecznych, gospodarczych i politycznych. U dziewcząt w tym przypadku widać też jak wielką wartość ma życie. Regulacja przeludnienia oznacza ingerencję w ludzkie życie, a dziewczęta w przyrodzie i środowisku widzą przede wszystkim życie. 冈o pytanie jest jednym z bardziej różnicujących ze względu na płeć.

\section{KORZYSTANIE Z ZASOBÓW ODNAWIALNYCH}

\section{Czy każdy człowiek ma prawo korzystać z zasobów odnawialnych w nie- ograniczonym zakresie?}

\begin{tabular}{|l|c|c|c|c|c|c|c|c|r|}
\hline \multicolumn{1}{|c|}{ \#B05 } & $\chi^{2}$ & Istotność & tak & $\begin{array}{c}\text { raczej } \\
\text { tak }\end{array}$ & $\begin{array}{r}\text { raczej } \\
\text { nie }\end{array}$ & nie & $\begin{array}{r}\text { trudno } \\
\text { powie- } \\
\text { dzieć. }\end{array}$ & $(\mathrm{BD})$ & LICZBA \\
\hline OGÓŁEM & & & $20.1 \%$ & $30.2 \%$ & $15.0 \%$ & $9.7 \%$ & $23.7 \%$ & $1.4 \%$ & 849 \\
\hline PŁEĆ & 13.47468 & 0.00917 & & & & & & & \\
chłopak & & & $24.5 \%$ & $30.4 \%$ & $14.2 \%$ & $10.9 \%$ & $18.7 \%$ & $1.4 \%$ & 359 \\
dziewczyna & & & $17.0 \%$ & $30.1 \%$ & $15.5 \%$ & $8.8 \%$ & $27.2 \%$ & $1.4 \%$ & 489 \\
\hline
\end{tabular}

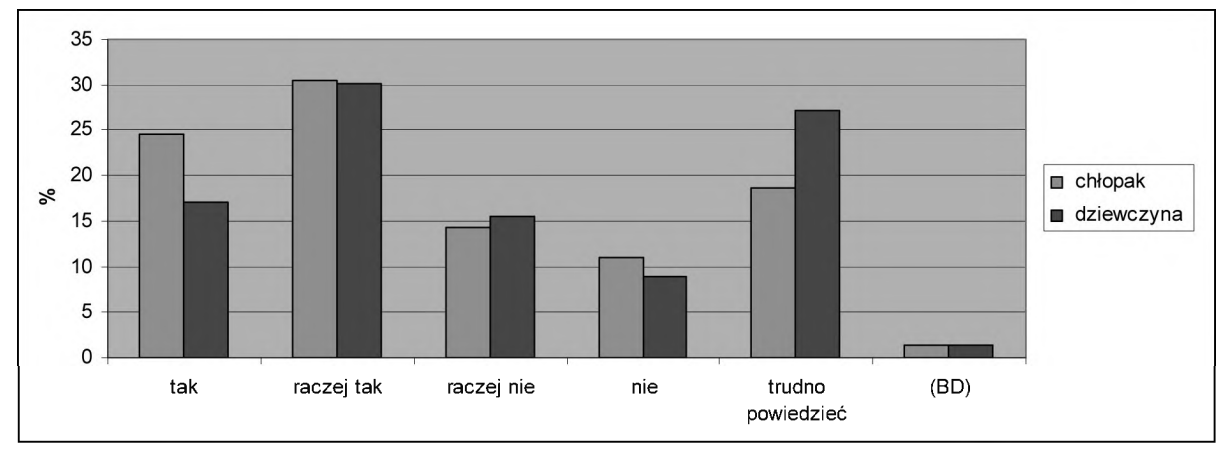

\ylko dwie odpowiedzi różnicują wyraźnie, „邓ak” i ta odpowiedź wskazuje na większą ilość chłopców (24,5\% - chłopcy i 17\% dziewczynki), którzy w sposób bardziej zdecydowany dają sobie prawo do korzystania z surowców nieodnawialnych w sposób nieograniczony. Druga odpowiedz, która też wyraźnie różnicuje, jest wątpliwość. Więcej problemów z jednoznaczną odpowiedzią mają dziewczyny. 


\section{SPOSÓB LIWIDACJI ŚMIECI}

\section{Jak Twoim zdaniem najlepiej likwidować śmieci?}

\begin{tabular}{|c|c|c|c|c|c|c|c|c|c|}
\hline$\underset{\#}{\stackrel{1}{*}}$ & 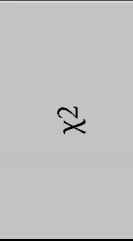 & 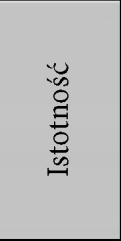 & 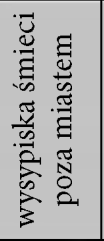 & 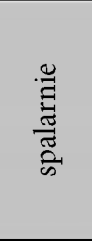 & 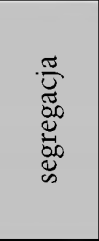 & $\begin{array}{l}\frac{w}{\hat{n}} \\
\frac{\hat{N}}{0} \\
0\end{array}$ & 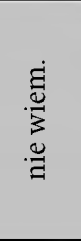 & $\widehat{\vartheta}$ & 芯 \\
\hline OGÓŁEM & & & $3.8 \%$ & $7.8 \%$ & $44.6 \%$ & $38.3 \%$ & $5.2 \%$ & $.4 \%$ & 849 \\
\hline PŁEĆ & 43.02548 & 0.00000 & & & & & & & \\
\hline chłopak & & & $4.7 \%$ & $10.9 \%$ & $32.0 \%$ & $46.2 \%$ & $5.8 \%$ & $.3 \%$ & 359 \\
\hline dziewczyna & & & $3.1 \%$ & $5.5 \%$ & $54.0 \%$ & $32.3 \%$ & $4.7 \%$ & $.4 \%$ & 489 \\
\hline
\end{tabular}

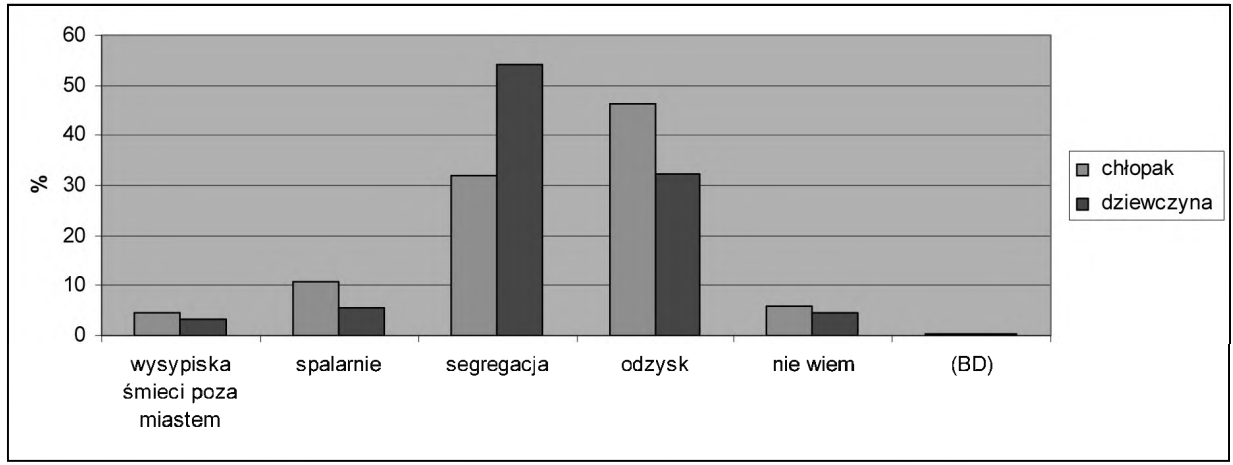

W odpowiedziach na pytanie o sposobie likwidacji śmieci widać duże zróżnicowanie między chłopcami a dziewczętami. Dziewczęta w sposób wyraźny opowiadają się za segregacją, chłopcy natomiast za konkretnymi metodami utylizującymi np. spalanie. Ciekawą sprawą jest, że chłopcy zamiast za segregacją opowiedzieli się za odzyskiem. Jeśli zastanowić się nad sensem, tych pojęć, to mają wspólne cel. Odzysk kojarzy się bardziej z czymś dokonanym, wiadomo, co i w jakim celu odzyskiwać. Celem segregacji jest odzysk, ale czynności związane z samym przygotowaniem i przeprowadzeniem segregacji są dla chłopców prawdopodobnie mniej konkretne i wyraźne. Spalarnie, wysypiska to mniej organizacji i pracy, często bezużytecznej w naszych realiach. Chłopcy chcą widzieć sens i skutek ich działań od razu, dziewczęta nie muszą widzieć natychmiastowego efektu, żeby poprzeć celowość jakiegoś przedsięwzięcia. 


\section{WYKORZYSTANIE WIEDZY EKOL. W PRAKTYCE}

Jak myślisz, czy umiesz wiedzę ekologiczną wykorzystać w praktyce. Czy korzystasz z prawa wyboru? Możesz zaznaczyć więcej niż jedną odpowiedź.

\begin{tabular}{|l|r|r|r|r|r|r|}
\hline$\#$ & $\begin{array}{c}\text { wybieram } \\
\text { produkt } \\
\text { ekologiczny }\end{array}$ & $\begin{array}{c}\text { wybieram } \\
\text { produkty } \\
\text { zdrowe }\end{array}$ & $\begin{array}{c}\text { unikam } \\
\text { produktów } \\
\text { zlych dla } \\
\text { zdrowia }\end{array}$ & $\begin{array}{c}\text { unikam } \\
\text { produktów } \\
\text { toksycz- } \\
\text { nych. }\end{array}$ & (BD) & LICZBA \\
\hline OGÓ£EM & $24.0 \%$ & $65.8 \%$ & $38.2 \%$ & $21.6 \%$ & $48.4 \%$ & 849 \\
\hline PŁÉ́ & $24.5 \%$ & $60.4 \%$ & $33.1 \%$ & $20.6 \%$ & $59.3 \%$ & 359 \\
chłopak & $23.5 \%$ & $69.7 \%$ & $41.9 \%$ & $22.3 \%$ & $40.5 \%$ & 489 \\
dziewczyna & & & & & & \\
\hline
\end{tabular}

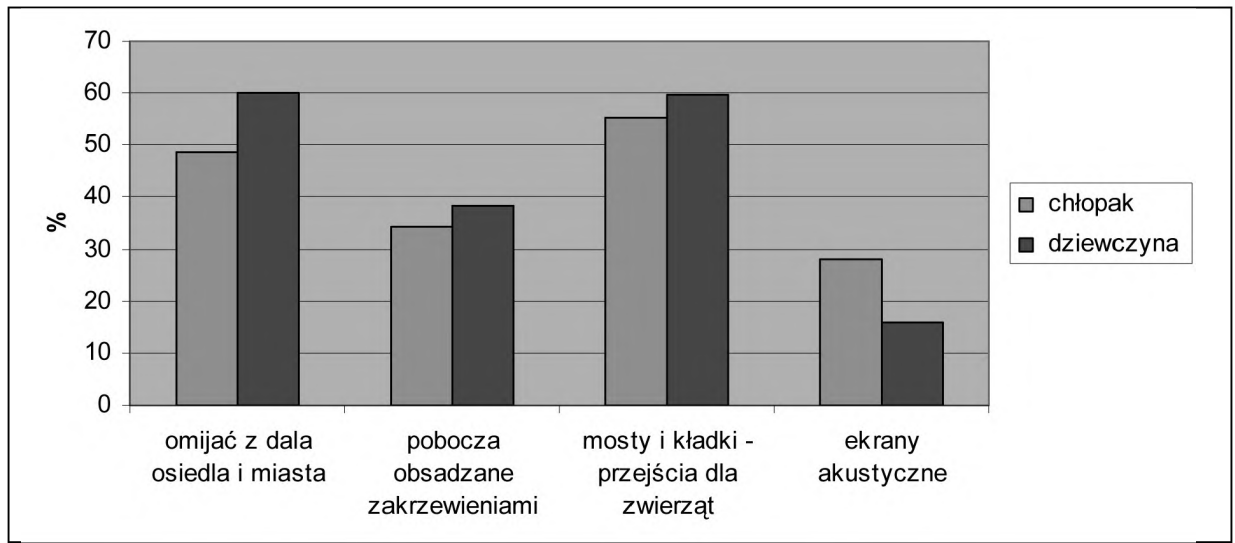

Po raz kolejny, gdy chodzi o zdrowie, czy bezpieczeństwo, dziewczęta wykazują większą troskę i podejmują działania zmniejszające ryzyko utraty zdrowia.

\section{WARUNKI DLA NOWYCH AUTOSTRAD}

Jakie warunki według Ciebie powinny spełniać nowo budowane autostrady? Wybierz dwa najważniejsze dla Ciebie.

\begin{tabular}{|l|r|r|r|r|r|r|}
\hline \multirow{1}{|c|}{$\#$} & $\begin{array}{c}\text { omijać } \\
\text { z dala } \\
\text { osiedla } \\
\text { i miasta }\end{array}$ & $\begin{array}{c}\text { pobocza } \\
\text { obsadzane } \\
\text { zakrzewie- } \\
\text { niami }\end{array}$ & $\begin{array}{c}\text { mosty } \\
\text { i kładki } \\
\text { - przejścia } \\
\text { dla zwierząt }\end{array}$ & $\begin{array}{c}\text { ekrany aku- } \\
\text { styczne. }\end{array}$ & (BD) & LICZBA \\
\hline OGÓŁEM & $55.2 \%$ & $36.6 \%$ & $58.0 \%$ & $21.0 \%$ & $28.9 \%$ & 849 \\
\hline PŁEĆ & $48.7 \%$ & $34.3 \%$ & $55.4 \%$ & $28.1 \%$ & $33.4 \%$ & 359 \\
chłopak & $60.1 \%$ & $38.2 \%$ & $59.7 \%$ & $15.7 \%$ & $25.6 \%$ & 489 \\
dziewczyna & & & & & \\
\hline
\end{tabular}




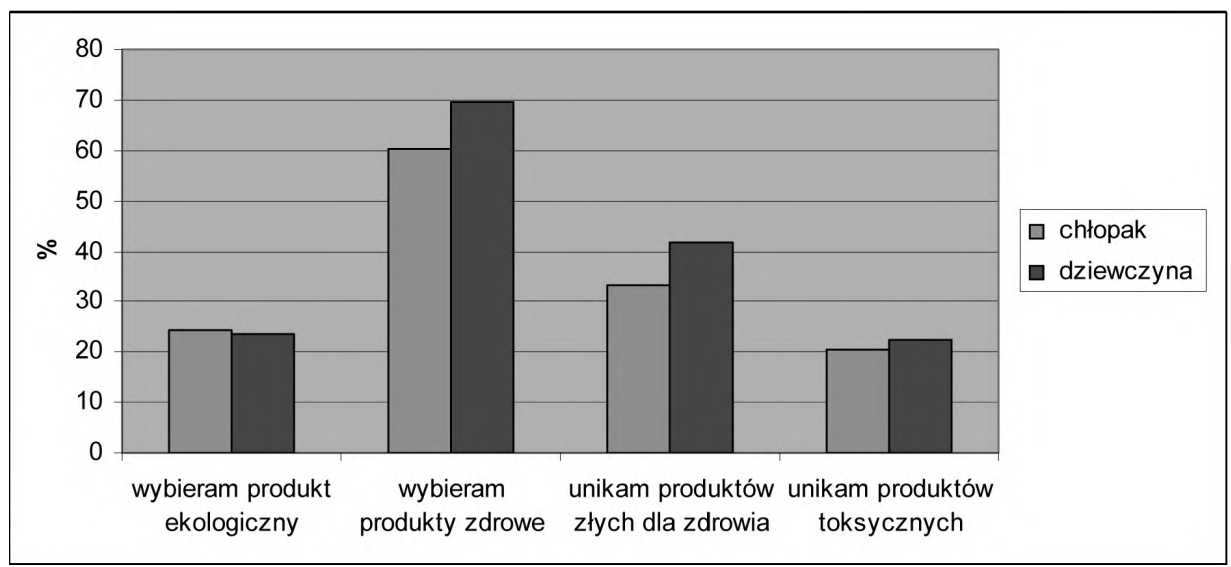

\e odpowiedzi w sposób nieomal klasyczny charakteryzują różnice płci w postrzeganiu problematyki związanej z użytkowaniem i ochroną środowiska. Dziewczynki konsekwentnie opowiadają się za zachowaniem środowiska, bez niepotrzebnej interwencji. Chłopcy natomiast chętniej realizują inwestycje, a nowoczesne rozwiązania technologiczne widzą jako sposób na minimalizowanie skutków antropopresji.

\section{POPRAWA STANU ŚRODOWISKA - WAŻNOŚĆ}

Od czego Twoim zdaniem zależy poprawa stanu środowiska? Odpowiedzi uszereguj na skali według ważności wpisując cyfry w kółka.

1. mało ważne

7. bardzo ważne 


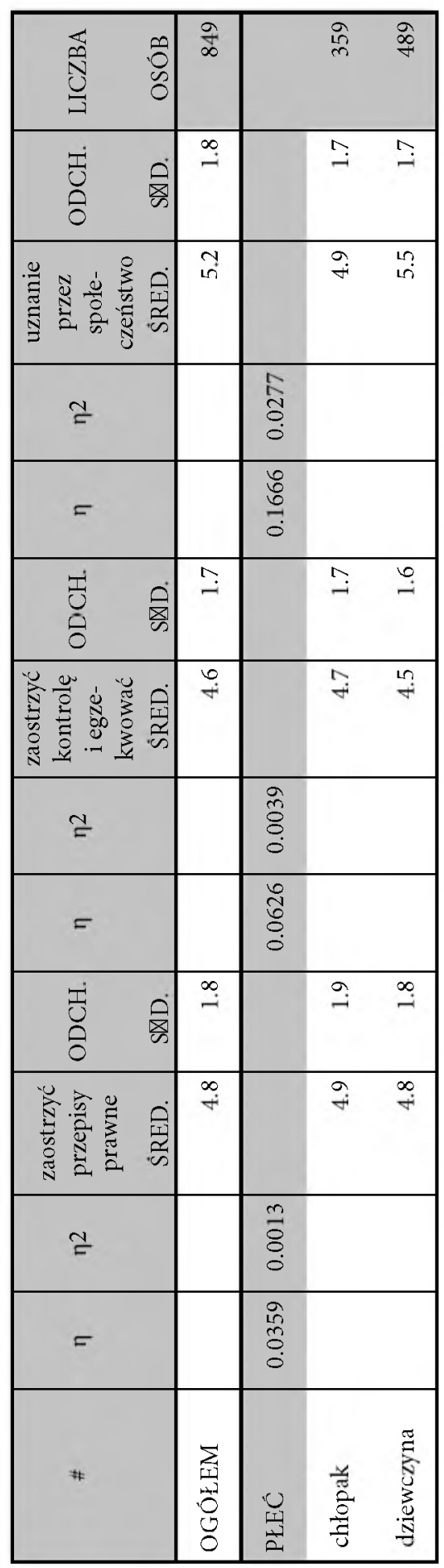

\begin{tabular}{|c|c|c|c|c|}
\hline 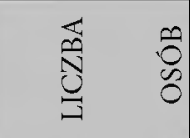 & $\underset{\infty}{2}$ & & in & $\stackrel{\infty}{\infty}$ \\
\hline $\begin{array}{ll}\dot{1} & \dot{\theta} \\
0 & \text { 齐 }\end{array}$ & $\stackrel{\circ}{\circ}$ & & $\cong$ & $\stackrel{0}{-}$ \\
\hline 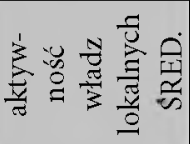 & $\stackrel{\dot{m}}{\dot{m}}$ & & $\begin{array}{l}\stackrel{0}{c} \\
\dot{r}\end{array}$ & $\tilde{r}$ \\
\hline$\stackrel{\Perp}{E}$ & & $\begin{array}{l}1 \\
8 \\
8 \\
0 \\
0\end{array}$ & & \\
\hline$=$ & & 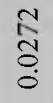 & & \\
\hline 焉 是 & $\stackrel{\circ}{\circ}$ & & 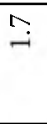 & $\stackrel{0}{-}$ \\
\hline 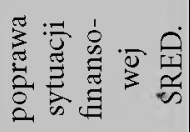 & $\ddot{n}$ & & $\begin{array}{l}\ddot{\varphi} \\
\dot{r}\end{array}$ & $\ddot{m}$ \\
\hline$\stackrel{I}{=}$ & & $\begin{array}{l}\frac{9}{8} \\
8 \\
0 \\
0\end{array}$ & & \\
\hline$=$ & & $\begin{array}{l}\vec{R} \\
0 \\
0 \\
0\end{array}$ & & \\
\hline 岂 & $\stackrel{2}{-}$ & & $?$ & $\stackrel{2}{2}$ \\
\hline 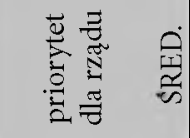 & $\stackrel{m}{+}$ & & $\stackrel{\sim}{\sim}$ & $\underset{\forall}{+}$ \\
\hline$\stackrel{\simeq}{=}$ & & $\begin{array}{l}\infty \\
\stackrel{8}{8} \\
\stackrel{0}{0}\end{array}$ & & \\
\hline$=$ & & $\begin{array}{l}\text { ర్ర } \\
0 \\
0\end{array}$ & & \\
\hline \# & $\begin{array}{l}\sum_{101} \\
\text { 戛 } \\
0 \\
0\end{array}$ & 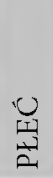 & 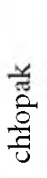 & 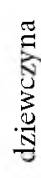 \\
\hline
\end{tabular}




\begin{tabular}{|l|r|r|r|r|r|}
\hline$\#$ & $\eta$ & $\eta 2$ & $\begin{array}{r}\text { trudno } \\
\text { powie- } \\
\text { dzieć } \\
\text { SRED. }\end{array}$ & ODCH. & LICZBA \\
\hline OGÓŁEM & & & 1.8 & 1.8 & OSÓB \\
\hline PŁEĆ & 0.0750 & 0.0056 & & & 849 \\
chłopak & & & 2.0 & 2.0 & 359 \\
dziewczyna & & & 1.7 & 1.7 & 489 \\
\hline
\end{tabular}

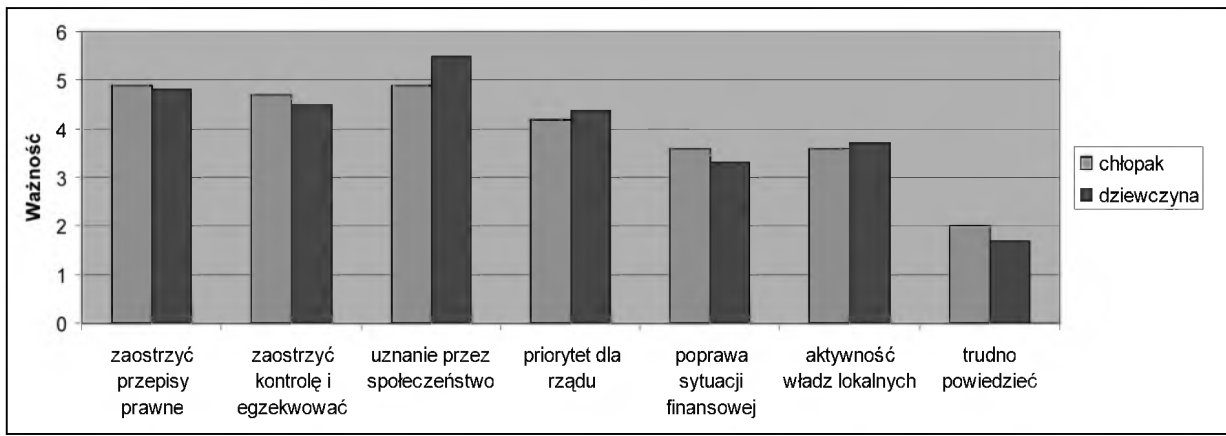

Poprawa środowiska jest ważnym zadaniem dla współczesnego pokolenia. Młodzi ludzie widzą szanse jego poprawy w różnych metodach i pomysłach działania. Chłopcy upatrują sukcesu w zaostrzonych przepisach prawnych, kontroli i ostrzejszym egzekwowaniu obowiązków oraz w poprawie finansowej. Dziewczęta natomiast widzą rozwiązanie w lepszej komunikacji społecznej, w aktywności władz oraz chętniej udzielają mandatu zaufania rządzącym. Dziewczęta w tych wypowiedziach potwierdzają swoją relacyjność i zainteresowania drugim człowiekiem.

\section{DZIELENIE Z GLODUJĄCYMI}

\section{Czy jesteś gotowy podzielić się chlebem z głodującymi w Chinach?}

\begin{tabular}{|c|c|c|c|c|c|c|c|}
\hline \#C01 & $x^{2}$ & Istotność & $\begin{array}{c}\text { tak } \\
\% \\
\end{array}$ & $\begin{array}{l}\text { nie } \\
\% \\
\end{array}$ & $\begin{array}{c}\text { nie } \\
\text { wiem. } \\
\% \\
\end{array}$ & $\begin{array}{c}\text { (BD) } \\
\% \\
\end{array}$ & $\begin{array}{c}\text { LICZBA } \\
\text { OSÓB } \\
\end{array}$ \\
\hline OGÓŁEM & & & $69.0 \%$ & $11.2 \%$ & $19.4 \%$ & $.3 \%$ & 849 \\
\hline PŁEĆ & 36.99614 & 0.00000 & & & & & \\
\hline chłopak & & & $59.9 \%$ & $18.4 \%$ & $21.2 \%$ & $.6 \%$ & 359 \\
\hline dziewczyna & & & & $5.9 \%$ & $18.2 \%$ & $.2 \%$ & 489 \\
\hline
\end{tabular}




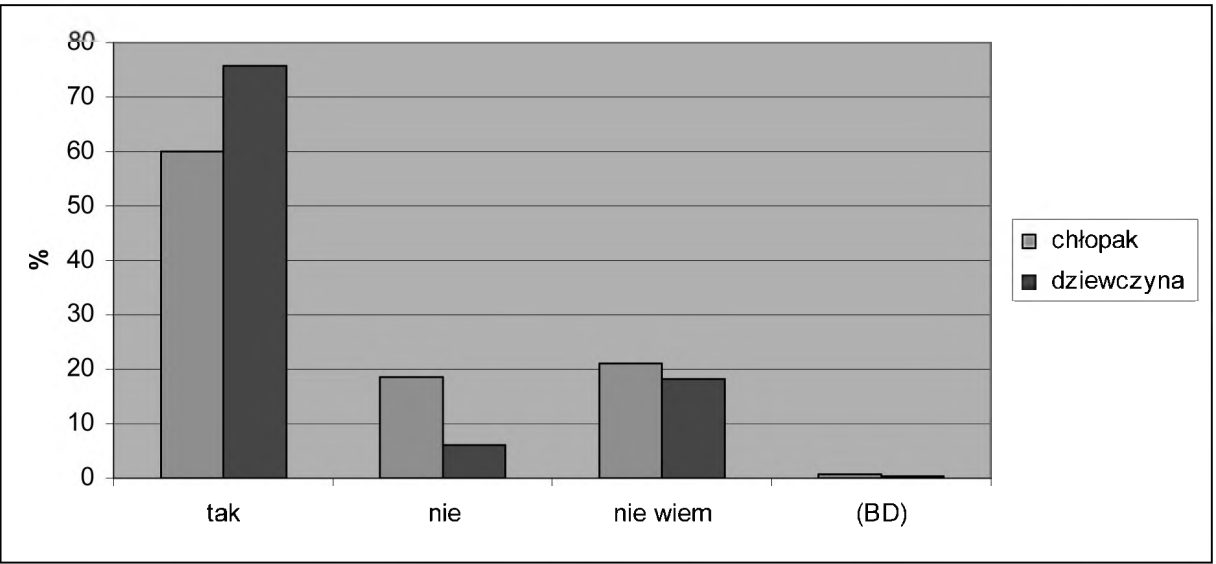

Dziewczęta w widoczny sposób deklarują pomoc głodującym. \e odpowiedzi świadczą o tym, że dziewczęta zwykle okazują więcej „miłosiernej” troski o drugiego człowieka. Chłopcy jako bardziej samodzielni, nie czują się w takim samym stopniu jak dziewczynki brać odpowiedzialności za drugiego człowieka. Chłopcy też częściej oceniają skuteczność działań, wierząc, że można być skuteczniejszym w działaniu, są też bardziej wymagający, egzekwujący i stąd prawdopodobnie takie zróżnicowanie w odpowiedziach. Dziewczęta są bardziej skłonne do kompromisu, poświęcenia, zrzeczenia się z czegoś na rzecz drugiego człowieka. 囚o zróżnicowanie w altruistycznych decyzjach różnicuje powyższe odpowiedzi.

\section{SPRAWIEDLIWY PODZIAL ŻYWNOŚCI}

Jak myślisz, czy ludzie mogliby tak gospodarować żywnością, aby nie było głodujących na świecie?

\begin{tabular}{|l|l|l|l|r|r|r|r|r|r|}
\hline \multicolumn{1}{|c|}{ \#C04 } & & tak & $\begin{array}{c}\text { raczej } \\
\text { tak }\end{array}$ & $\begin{array}{c}\text { raczej } \\
\text { nie }\end{array}$ & nie & $\begin{array}{c}\text { nie } \\
\text { mam } \\
\text { zdania. }\end{array}$ & (BD) & LICZBA \\
\hline OGÓŁEM & & & $32.2 \%$ & $41.9 \%$ & $15.0 \%$ & $4.9 \%$ & $5.7 \%$ & $.3 \%$ & 849 \\
\hline PŁEĆ & 14.721161 & 0.00531 & & & & & & & \\
chłopak & & & $29.5 \%$ & $40.4 \%$ & $16.4 \%$ & $8.1 \%$ & $5.6 \%$ & $.0 \%$ & 359 \\
dziewczyna & & & $33.9 \%$ & $43.1 \%$ & $13.9 \%$ & $2.7 \%$ & $5.7 \%$ & $.6 \%$ & 489 \\
\hline
\end{tabular}




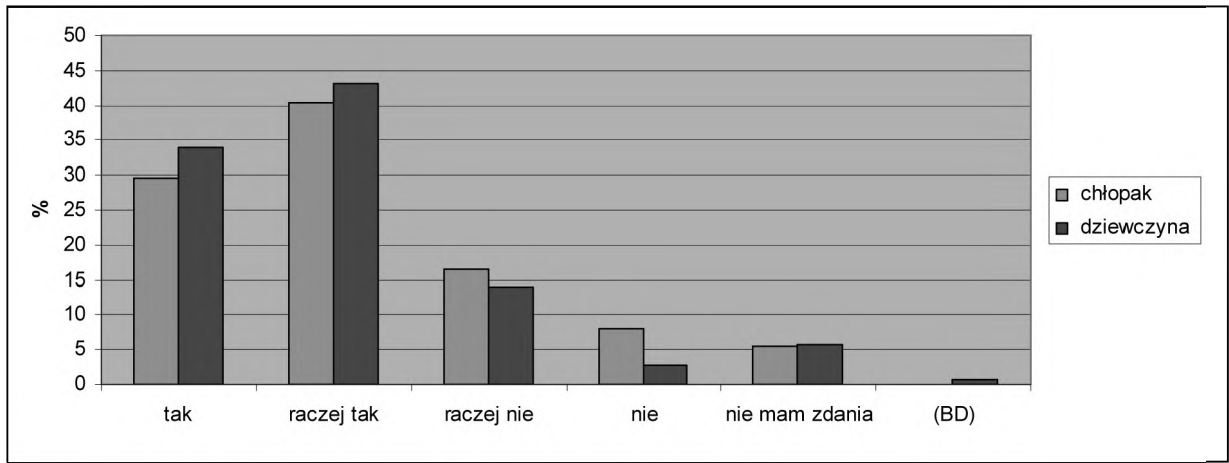

Dziewczęta bardziej wierzą w to, że jest taka możliwość i że sprawiedliwy podział np. żywności będzie realizowany. Same wykazują większą gotowość dzielenia się z innymi, więc również $\mathrm{w}$ większym procencie są przekonane, że inni są też skłonni tak gospodarować, aby zaradzić skutkom głodu.

\section{INNE ŻYCIE WARTE TYLE, CO TWOJE?}

\section{Czy życie innego człowieka jest tyle samo warte, co Twoje?}

\begin{tabular}{|l|l|l|r|r|r|r|r|}
\hline \multicolumn{1}{|c|}{ \#C05 } & & & tak & \multicolumn{1}{c|}{ nie } & to zależy. & (BD) & LICZBA \\
\hline OGÓŁEM & & & $75.6 \%$ & $6.1 \%$ & $17.8 \%$ & $.5 \%$ & 849 \\
\hline PŁEĆ & 41.07670 & 0.00000 & & & & & \\
chłopak & & & $65.2 \%$ & $10.6 \%$ & $23.7 \%$ & $.6 \%$ & 359 \\
dziewczyna & & & $83.2 \%$ & $2.9 \%$ & $13.5 \%$ & $.4 \%$ & 489 \\
\hline
\end{tabular}

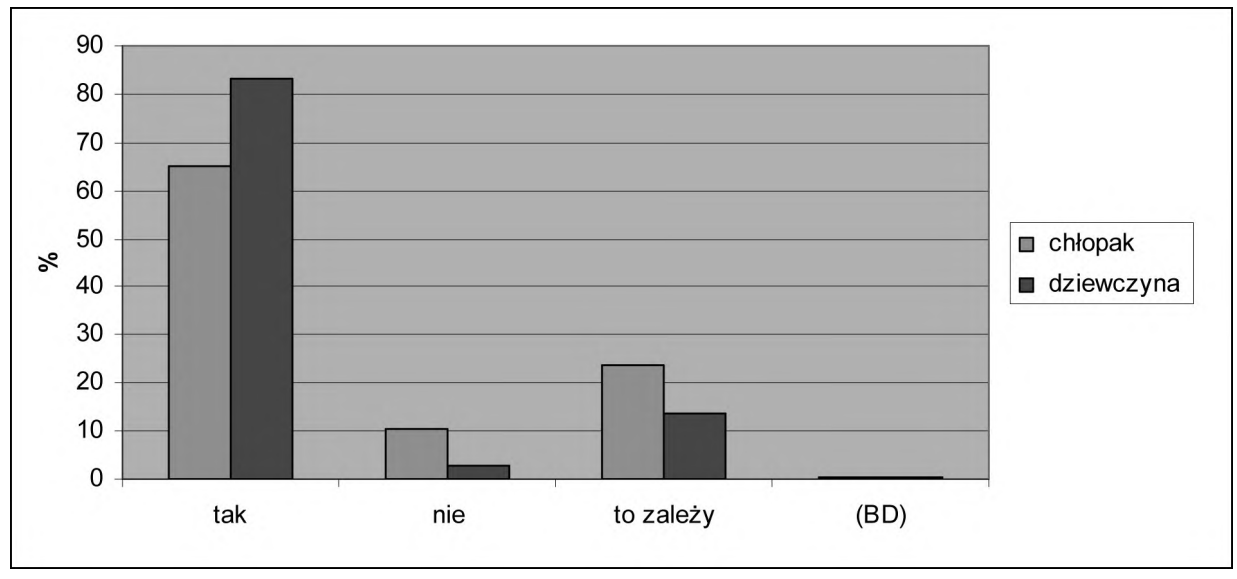


W tej tak bardzo znaczącej odpowiedzi, bo chodzi o bezpośrednią wypowiedź dotyczącą wartości życia, dziewczęta w sposób znacznie wyraźniejszy opowiadają się za równością życia wszystkich ludzi. Nie stawiają swojego życia ponad inne. Może to wynikać $z$ faktu, że to kobieta jest przygotowywana w swoje przyrodzoności jako pierwsza do przyjęcia, ochrony i pielęgnowania życia.

\section{NIEZALEŻNOŚĆ OD INNYCH}

\section{Czy jest możliwe, aby człowiek był niezależny od innych?}

\begin{tabular}{|l|r|r|r|r|r|r|}
\hline \multicolumn{1}{|c|}{ \#C06 } & & & \multicolumn{1}{c|}{ बak } & \multicolumn{1}{c|}{ nie } & \multicolumn{1}{c|}{ (BD) } & \multicolumn{1}{c|}{ LICZBA } \\
\hline OGOŁEM & & & $39.2 \%$ & $60.0 \%$ & $.9 \%$ & 849 \\
\hline PŁEĆ & 13.38884 & 0.00025 & & & & \\
chłopak & & & $46.5 \%$ & $53.2 \%$ & $.3 \%$ & 359 \\
dziewczyna & & & $33.7 \%$ & $65.0 \%$ & $1.2 \%$ & 489 \\
\hline
\end{tabular}

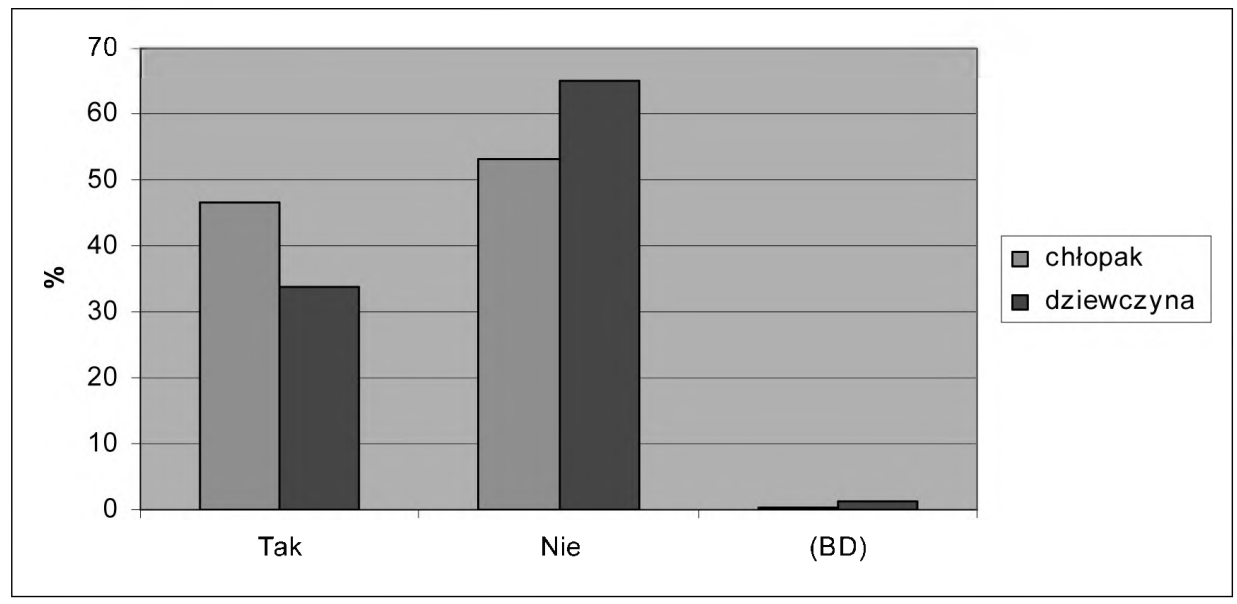

\a odpowiedź również różnicuje według schematu. 囚o pytanie jest odwrotnością pytania o wspólnotowy charakter ludzkości. Chłopcy w swojej samodzielności i samowystarczalności uważają, że mogą być niezależni od innych. 


\section{FORMY ODDZIAŁYWANIA NA SPOŁECZEŃSTWO}

\section{Co Twoim zdaniem najskuteczniej oddziałuje na społeczeństwo?}

\begin{tabular}{|l|l|l|c|c|c|c|c|c|}
\hline \#C13 & & edukacja & $\begin{array}{c}\text { publi- } \\
\text { cystyka }\end{array}$ & $\begin{array}{c}\text { egzekwo- } \\
\text { wanie } \\
\text { prawa }\end{array}$ & $\begin{array}{c}\text { inter- } \\
\text { wencje. }\end{array}$ & (BD) & LICZBA \\
\hline OGÓ£EM & & & $17.1 \%$ & $50.4 \%$ & $17.1 \%$ & $13.5 \%$ & $1.9 \%$ & 849 \\
\hline PŁEĆ & 33.90694 & 0.00000 & & & & & & \\
\hline chłopak & & & $19.2 \%$ & $39.0 \%$ & $21.7 \%$ & $17.8 \%$ & $2.2 \%$ & 359 \\
\hline dziewczyna & & & $15.5 \%$ & $58.7 \%$ & $13.7 \%$ & $10.4 \%$ & $1.6 \%$ & 489 \\
\hline
\end{tabular}

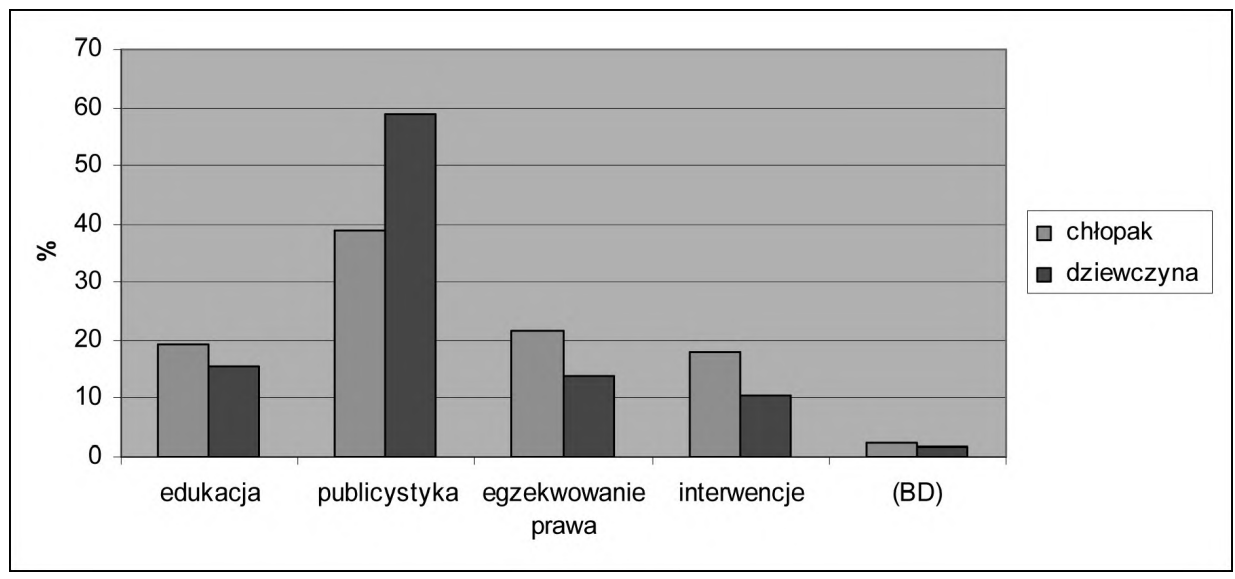

Nawet w sposobie oddziaływań widać różnice, które wynikają z odmiennych predyspozycji płci. Dziewczęta stawiają na różne formy publicystyki, które dotyczą szerokich mas. Chłopcy skuteczność oddziaływań widzą w egzekwowaniu prawa, edukacji i interwencjach. Dziewczęta wyraźniej upatrują szansy zachowania przyrody w różnego rodzaju akcjach. Forma protestu może być dla nich sposobem komunikowania się, buntu. Natomiast przeciw strajkom i protestom na rzecz konkretnych koncepcji w sposób zdecydowany wypowiadają się chłopcy.

\section{POMOC PAŃSTW BOGATYCH DLA BIEDNYCH}

Czy kraje bogate powinny coś zrobić, aby mieć wpływ na przyrost demograficzny w krajach biednych? 


\begin{tabular}{|l|c|c|c|c|c|c|c|}
\hline \multicolumn{1}{|c|}{ \#D01 } & & & tak & nie & $\begin{array}{c}\text { brak } \\
\text { zdania. }\end{array}$ & (BD) & LICZBA \\
\hline OGÓŁEM & & & $63.0 \%$ & $9.1 \%$ & $27.4 \%$ & $.4 \%$ & $\mathbf{8 4 9}$ \\
\hline PŁÉ́ & $\mathbf{2 1 . 2 6 7 8 6}$ & $\mathbf{0 . 0 0 0 0 2}$ & & & & & \\
chłopak & & & $61.8 \%$ & $14.2 \%$ & $23.7 \%$ & $.3 \%$ & $\mathbf{3 5 9}$ \\
dziewczyna & & & $63.8 \%$ & $5.3 \%$ & $30.3 \%$ & $.6 \%$ & $\mathbf{4 8 9}$ \\
\hline
\end{tabular}

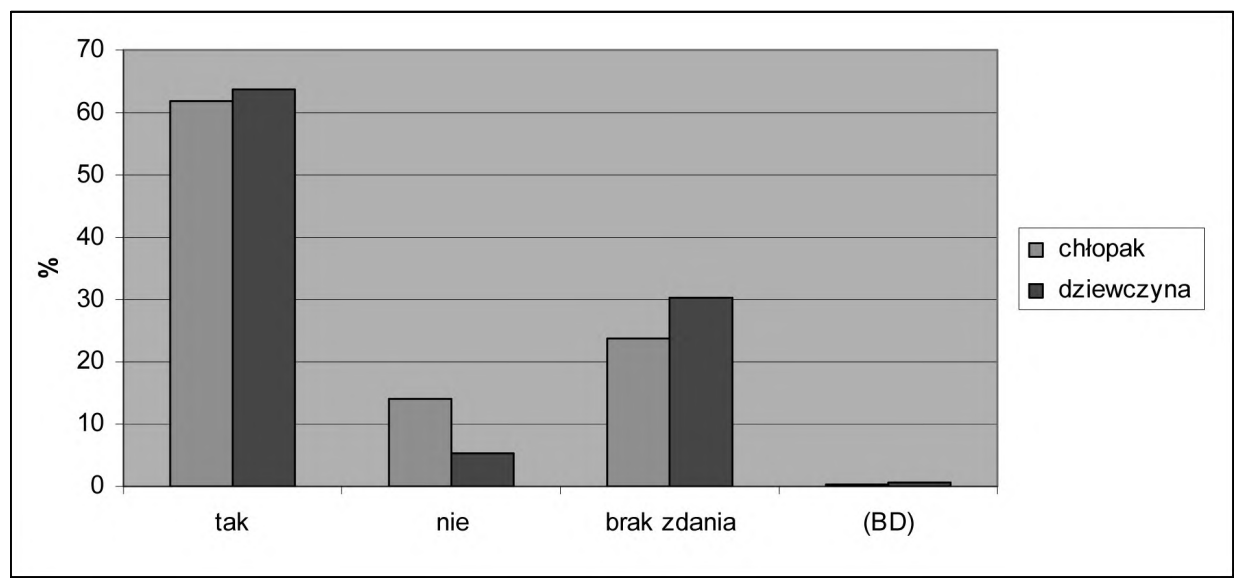

Qutaj widać konsekwencję w sposobie myślenia chłopców i dziewcząt. Chociaż chłopcy w innym pytaniu dostrzegali problem demograficzny w świecie, to w przypadku interwencji bardziej są skłonni nie wtrącać się. Podobnie, chociaż w sposób wyraźniejszy nie deklarowali chęci pomocy krajom biednym. Dziewczęta wykazały stanowisko, które wyraźnie różnicuje wypowiedzi chłopców.

\section{RESPEKTOWANIE KONWENCJI}

Czy powinniśmy jako kraj ograniczać produkcję szkodliwych substancji, ze względu na zawarte konwencje z sąsiadującymi krajami, nawet, jeżeli zmniejsza to dla nas korzystną produkcję?

\begin{tabular}{|l|c|c|c|c|c|c|c|c|}
\hline \multicolumn{1}{|c|}{ \#D04 } & & & tak & nie & to zależy & $\begin{array}{c}\text { nie mam } \\
\text { zdania. }\end{array}$ & (BD) & LICZBA \\
\hline OGÓŁEM & & & $52.5 \%$ & $7.3 \%$ & $26.7 \%$ & $13.3 \%$ & $.1 \%$ & $\mathbf{8 4 9}$ \\
\hline PŁEĆ & $\mathbf{3 2 . 2 1 4 2 6}$ & $\mathbf{0 . 0 0 0 0 0}$ & & & & & & \\
chłopak & & & $50.4 \%$ & $12.5 \%$ & $27.6 \%$ & $9.2 \%$ & $.3 \%$ & $\mathbf{3 5 9}$ \\
dziewczyna & & & $54.0 \%$ & $3.5 \%$ & $26.2 \%$ & $16.4 \%$ & $.0 \%$ & $\mathbf{4 8 9}$ \\
\hline
\end{tabular}




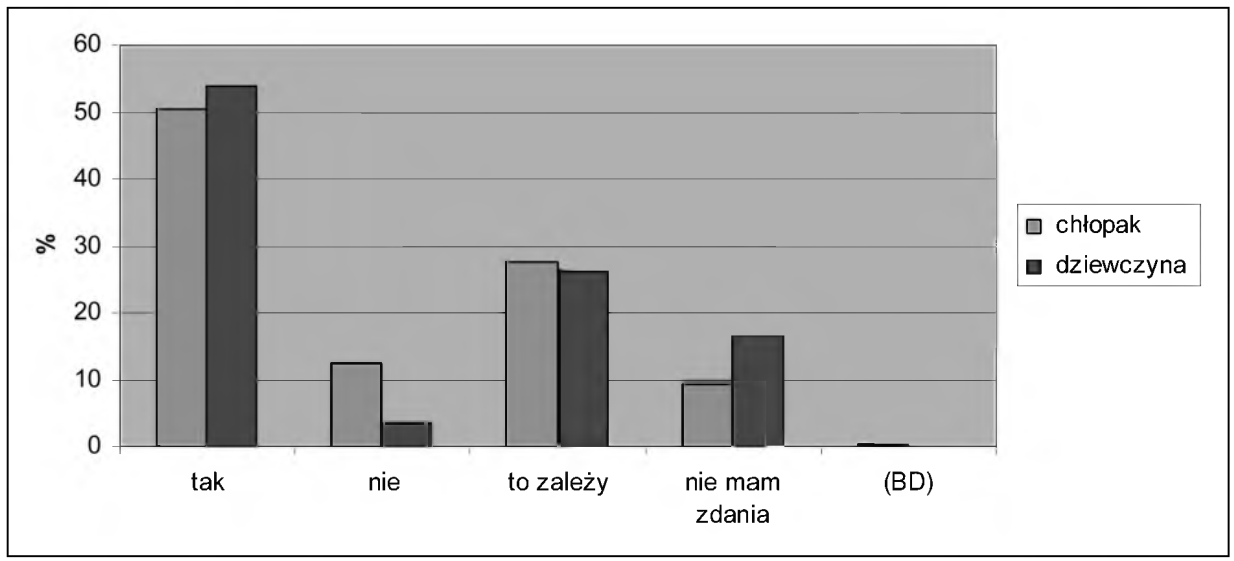

Dziewczęta deklarują gotowość ograniczeń na rzecz innych krajów, chłopcy natomiast mniej chętnie opowiadają się za takim rozwiązaniem. U chłopców w wieku odpowiedziach dawało się zauważyć niechęć do ograniczeń i wyrzeczeń.

\section{PRZYSZłOSĆ SWIATA}

\section{Przyszłość świata widzisz.}

\begin{tabular}{|c|c|c|c|c|c|c|c|}
\hline \#D05 & & & $\begin{array}{c}\text { nowa era } \\
\text { ekolo- } \\
\text { giczna }\end{array}$ & $\begin{array}{c}\text { miasto } \\
\text { świat }\end{array}$ & $\begin{array}{c}\text { równo- } \\
\text { waga } \\
\text { przyroda } \\
\text { - czło- } \\
\text { wiek. }\end{array}$ & (BD) & LICZBA \\
\hline OGÓŁEM & & & $15.2 \%$ & $28.6 \%$ & $54.3 \%$ & $1.9 \%$ & 849 \\
\hline PŁEĆ & 25.84283 & 0.00000 & & & & & \\
\hline chłopak & & & $18.7 \%$ & $34.8 \%$ & $44.0 \%$ & $2.5 \%$ & 359 \\
\hline dziewczyna & & & $12.5 \%$ & $24.1 \%$ & $62.0 \%$ & $1.4 \%$ & 489 \\
\hline
\end{tabular}




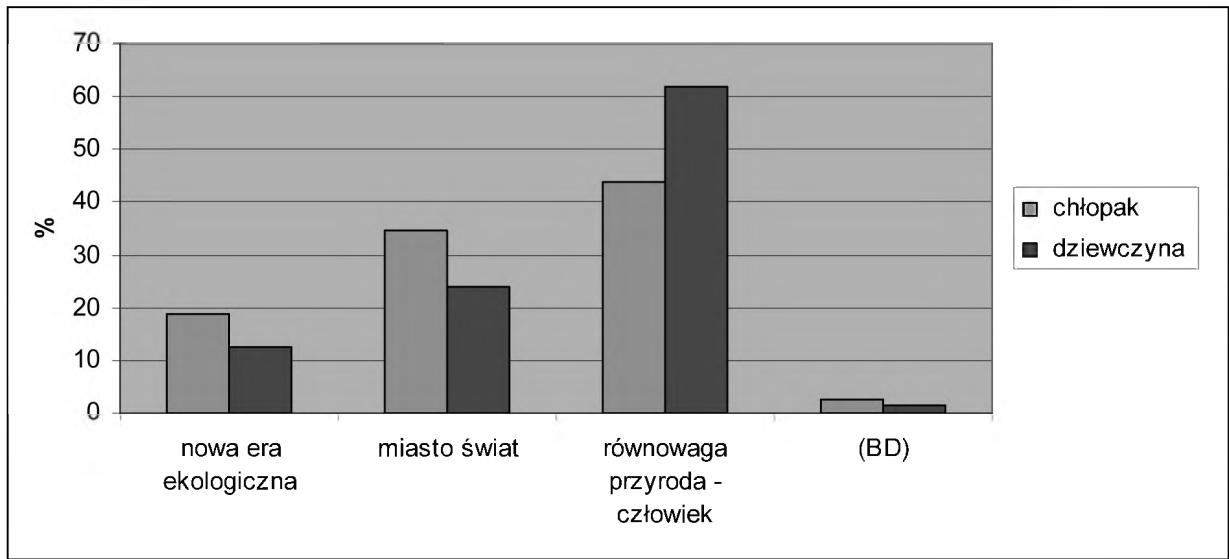

Dziewczęta przyszłość świata widzą w zachowaniu przyrody, harmonii i przede wszystkim w równowadze między ochroną a przekształcaniem jej. Chłopów charakteryzuje wybór nowych rozwiązań technicznych, technologicznych i wdrażanie ich w codzienne życie, nawet kosztem zubożenia środowiska naturalnego. Rekultywacja, restytucja i inne przedsięwzięcia mogą się też udać stosują nowe rozwiązania technologiczne.

\section{CELE KSZTAŁTOWANIA ŚWIADOMOŚCI EKOLOGICZNEJ}

Jakie Twoim zdaniem są najważniejsze cele kształtowania świadomości ekologicznej? Te, które Twoim zdaniem są niezbędne w edukacji zaznacz (przynajmniej trzy).

\begin{tabular}{|c|c|c|c|c|c|c|c|c|c|c|}
\hline$\#$ & 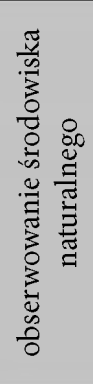 & 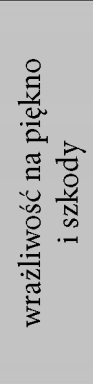 & 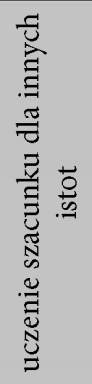 & 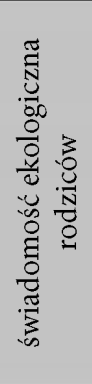 & 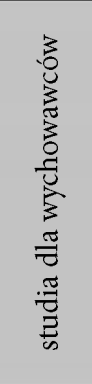 & 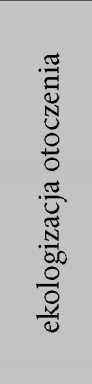 & 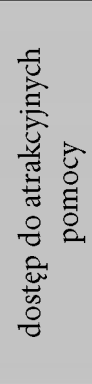 & 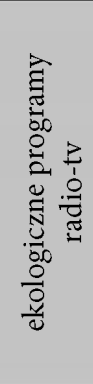 & 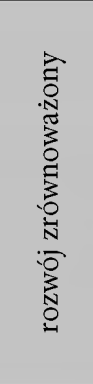 & 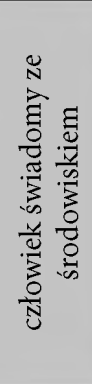 \\
\hline OGÓEEM & $20.6 \%$ & $40.3 \%$ & $43.3 \%$ & $19.8 \%$ & $15.0 \%$ & $22.1 \%$ & $13.7 \%$ & $25.1 \%$ & $9.5 \%$ & $28.0 \%$ \\
\hline \multicolumn{11}{|l|}{ PŁEĆ } \\
\hline chłopak & $19.5 \%$ & $32.3 \%$ & $35.1 \%$ & $23.1 \%$ & $18.4 \%$ & $23.7 \%$ & $17.5 \%$ & $21.4 \%$ & $12.3 \%$ & $25.3 \%$ \\
\hline $\begin{array}{l}\text { dziewczy- } \\
\text { na }\end{array}$ & $21.5 \%$ & $46.0 \%$ & $49.5 \%$ & $17.4 \%$ & $12.5 \%$ & $21.1 \%$ & $10.8 \%$ & $27.6 \%$ & $7.6 \%$ & $29.9 \%$ \\
\hline
\end{tabular}




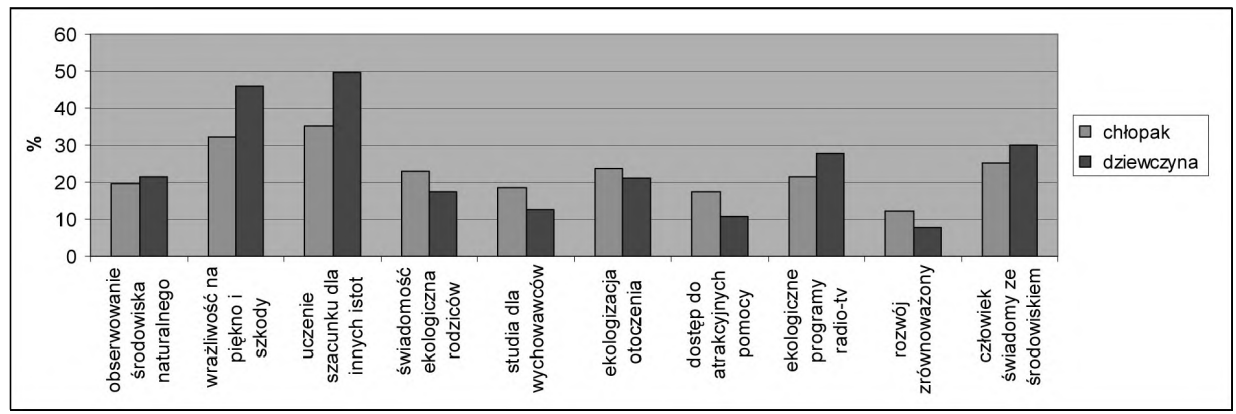

Dziewczęta wybrały takie cele jak: wrażliwość i piękno przyrody, uczenie szacunku dla innych oraz świadomość ekologiczna. Chłopcy wybrali ekologizację otoczenia, dostęp do atrakcyjnych pomocy i świadomość ekologiczną rodziców.

\section{CELE KSZTAŁTOWANIA ŚWIADOMOŚCI EKOLOGICZNEJ}

Jakie Twoim zdaniem są najważniejsze cele kształtowania świadomości ekologicznej? Te, które Twoim zdaniem są niezbędne w edukacji zaznacz (przynajmniej trzy).

\begin{tabular}{|l|c|c|c|c|c|c|}
\hline$\#$ & $\begin{array}{c}\text { poznanie } \\
\text { praw } \\
\text { przyrody }\end{array}$ & $\begin{array}{c}\text { system } \\
\text { wartości }\end{array}$ & $\begin{array}{c}\text { szacunek } \\
\text { dla życia }\end{array}$ & $\begin{array}{c}\text { edukacja } \\
\text { w tere- } \\
\text { nie. }\end{array}$ & (BD) & LICZBA \\
\hline OGÓŁEM & $18.6 \%$ & $16.1 \%$ & $26.1 \%$ & $24.4 \%$ & $99.2 \%$ & $\mathbf{8 4 9}$ \\
\hline PŁÉ́ & & & & & & \\
chłopak & $16.7 \%$ & $16.4 \%$ & $20.3 \%$ & $23.4 \%$ & $99.7 \%$ & $\mathbf{3 5 9}$ \\
dziewczyna & $20.0 \%$ & $15.7 \%$ & $30.5 \%$ & $25.2 \%$ & $98.8 \%$ & $\mathbf{4 8 9}$ \\
\hline
\end{tabular}

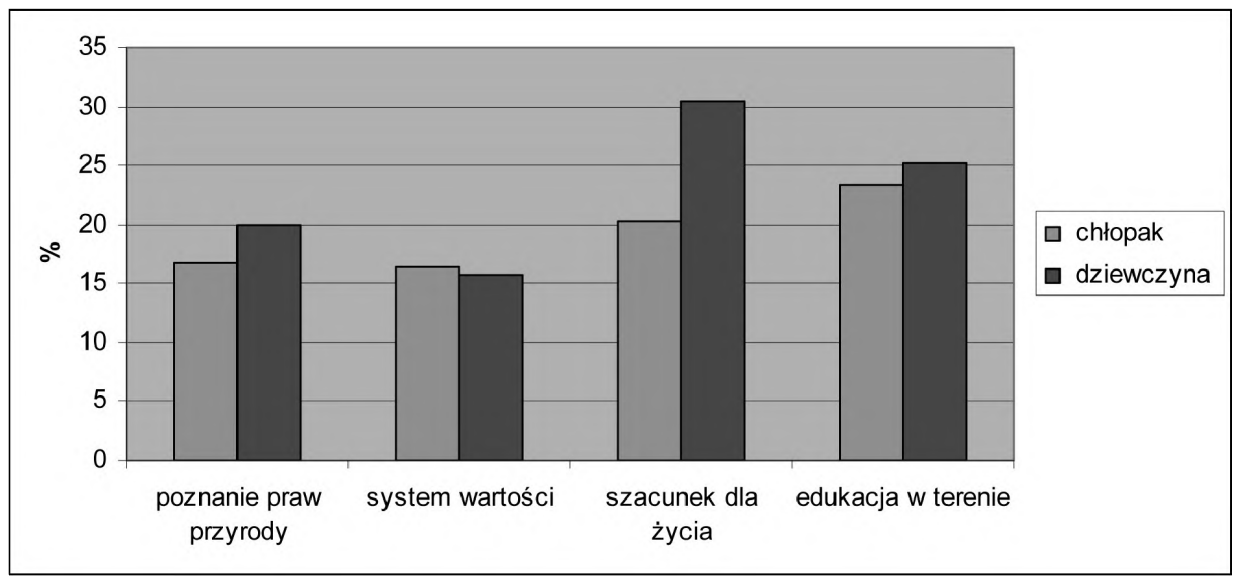


\o pytanie najbardziej pokazuje jak kobiety mogą wpływać na kształtowanie świadomości ekologicznej. Szukanie prawdy o przyrodzie, szacunek do wszelkich form życia to dla dziewcząt ważniejsze wybory. Chłopcy nieznacznie przeważają w wyborze systemu wartości, a więc można uznać, że jest to wybór najbardziej teoretyczny. System wartości jest już wytworem umysłów ludzkich, i najczęściej właśnie męskich.

\section{RESPONDENCI O INWESTYCJACH NA TRANSPORT KOLEJOWY}

Transport kolejowy samochodów ciężarowych od granicy do granicy wiąże się z przebudową infrastruktury kolei oraz wybudowaniu około 10 ogromnych stacji załadunkowo-rozładunkowych. Inwestycja taka jest ogromna i na lata. Czy warto jednak, aby rząd naszego kraju poważnie o tym myślał?

\begin{tabular}{|l|c|c|c|c|c|c|c|}
\hline \#D12 & & & tak & Nie & $\begin{array}{c}\text { Nie } \\
\text { wiem }\end{array}$ & (BD) & LICZBA \\
\hline OGÓŁEM & & & $39.8 \%$ & $14.1 \%$ & $44.4 \%$ & $1.6 \%$ & $\mathbf{8 4 9}$ \\
\hline PŁEĆ & $\mathbf{3 9 . 7 1 9 0 0}$ & $\mathbf{0 . 0 0 0 0 0}$ & & & & & \\
chłopak & & & $49.3 \%$ & $17.3 \%$ & $32.3 \%$ & $1.1 \%$ & $\mathbf{3 5 9}$ \\
dziewczyna & & & $32.7 \%$ & $11.9 \%$ & $53.4 \%$ & $2.0 \%$ & $\mathbf{4 8 9}$ \\
\hline
\end{tabular}

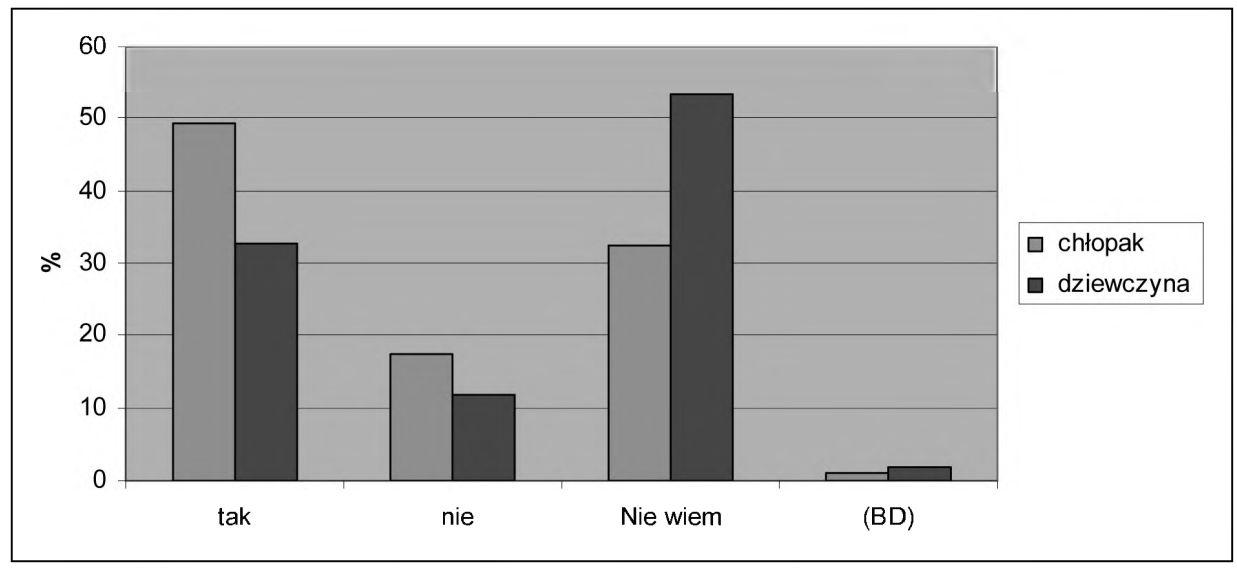

Chłopcy w tym i wielu podobnych pytaniach odpowiadają, że warto inwestować, stosować nowe technologie, nawet kosztem zubożenia środowiska naturalnego. W tym wypadku w sposób wyraźny popierają budowę trans - kolei. 


\section{WYBÓR PRZYRODA/GOSPODARKA}

\section{Co jest dla ciebie ważniejsze?}

\begin{tabular}{|c|c|c|c|c|c|c|c|}
\hline \#D13 & & & przyroda & $\begin{array}{c}\text { obie jed- } \\
\text { nakowo }\end{array}$ & $\begin{array}{c}\text { gospo- } \\
\text { darka }\end{array}$ & (BD) & LICZBA \\
\hline OGÓŁEM & & & $21.3 \%$ & $67.0 \%$ & $9.7 \%$ & $2.0 \%$ & 849 \\
\hline PŁEĆ & $\mathbf{2 2 . 6 6 0 1 5}$ & $\mathbf{0 . 0 0 0 0 1}$ & & & & & \\
chłopak & & & $20.3 \%$ & $62.4 \%$ & $15.3 \%$ & $2.0 \%$ & 359 \\
dziewczyna & & & $21.9 \%$ & $70.6 \%$ & $5.5 \%$ & $2.0 \%$ & 489 \\
\hline
\end{tabular}

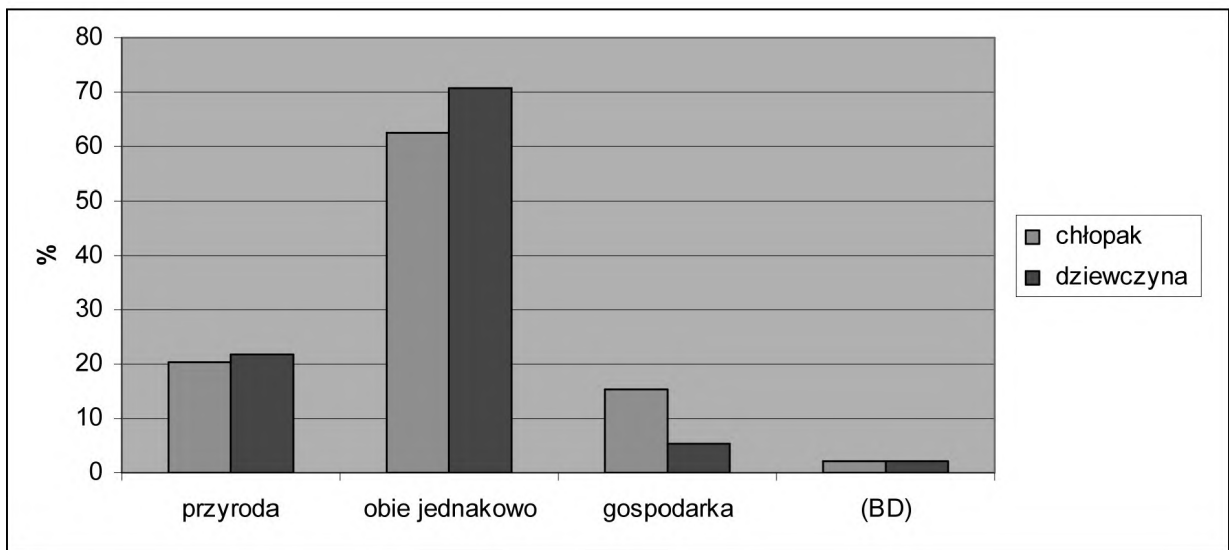

Zdecydowanie zarówno dla chłopców jak i dla dziewcząt ważna jest i przyroda i gospodarka, ale procentowo w tym wyborze dominują dziewczęta. Drugie, co do ważności to przyroda i tutaj też dla obu płci, z tym, że liczebnie przeważają dziewczynki. Ørzecia, co do ważności to gospodarka i za taką opcją opowiada się więcej chłopców.

\section{ZAKUPY Z WŁASNYMI TORBAMI}

\section{Czy idąc na zakupy bierzesz ze sobą swoje torby?}

\begin{tabular}{|l|c|c|c|c|c|c|c|c|c|}
\hline \#E03 & $\chi^{2}$ & Istotność & tak & $\begin{array}{c}\text { chcia- } \\
\text { cza- } \\
\text {-sami }\end{array}$ & $\begin{array}{c}\text { tabym, } \\
\text { ale nie } \\
\text { pamię- } \\
\text { tam }\end{array}$ & $\begin{array}{c}\text { raczej } \\
\text { nie }\end{array}$ & nie. & (BD) & LICZBA \\
\hline OGÓ£EM & & & $24.3 \%$ & $38.3 \%$ & $10.1 \%$ & $10.5 \%$ & $16.4 \%$ & $.5 \%$ & $\mathbf{8 4 9}$ \\
\hline PŁEĆ & 20.44152 & $\mathbf{0 . 0 0 0 4 1}$ & & & & & & & \\
chłopak & & & $19.8 \%$ & $34.3 \%$ & $12.3 \%$ & $12.0 \%$ & $21.2 \%$ & $.6 \%$ & 359 \\
dziewczyna & & & $27.6 \%$ & $41.1 \%$ & $8.6 \%$ & $9.4 \%$ & $12.9 \%$ & $.4 \%$ & $\mathbf{4 8 9}$ \\
\hline
\end{tabular}




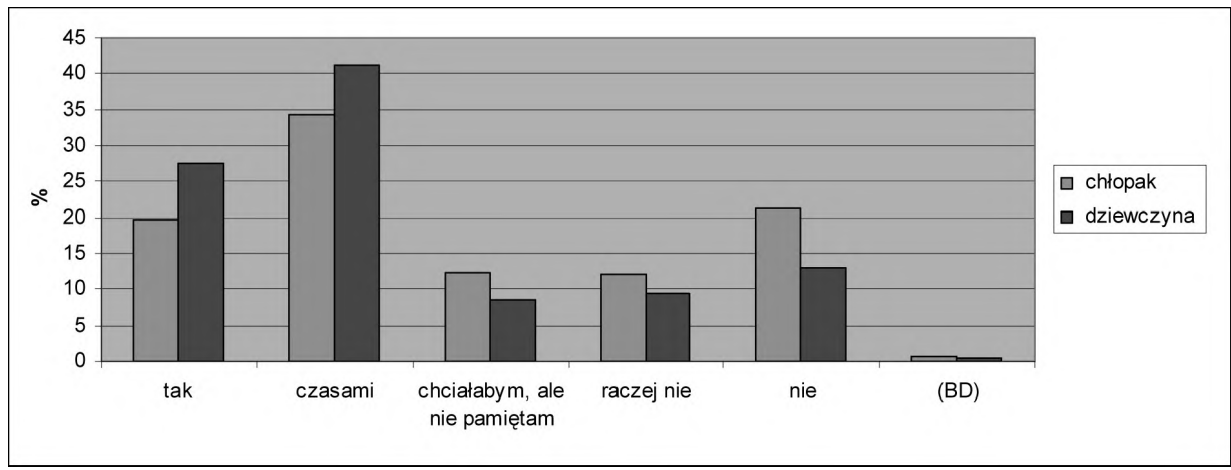

Codzienne drobne czynności, wymagające uważności w ich realizowaniu deklarują w większym procencie dziewczyny.

\section{KORZYSTANIE Z FAST FOOD}

Wiesz, że w sieci sklepów „Fast food” np. Mc Donalds, czy Burger King jedzenie jest niepełnowartościowe, sporządzone z najgorszych części i w dodatku niezdrowe. Jeżeli jesteś w pobliżu takiej restauracji i jesteś głodny, co robisz?

\begin{tabular}{|l|c|c|c|c|c|c|c|c|}
\hline \#E10 & $\chi^{2}$ & Istotnośćć & $\begin{array}{c}\text { tak -czy- } \\
\text { sto, miło, } \\
\text { smacznie }\end{array}$ & $\begin{array}{c}\text { muszé } \\
\text { zjeść } \\
- \text { miła } \\
\text { i szybka } \\
\text { obsługa }\end{array}$ & $\begin{array}{c}\text { nie } \\
\text { popie- } \\
\text { ram tej } \\
\text { działal- } \\
\text { ności }\end{array}$ & $\begin{array}{c}\text { z zasady } \\
\text { nie ko- } \\
\text { rzystam. }\end{array}$ & (BD) & LICZBA \\
\hline OGÓŁEM & & & $31.6 \%$ & $38.0 \%$ & $10.7 \%$ & $18.7 \%$ & $1.0 \%$ & 849 \\
\hline PŁEĆ & $\mathbf{3 . 7 7 5 0 1}$ & $\mathbf{0 . 2 8 6 8 1}$ & & & & & & \\
chłopak & & & $32.9 \%$ & $38.2 \%$ & $11.7 \%$ & $15.9 \%$ & $1.4 \%$ & 359 \\
dziewczyna & & & $30.7 \%$ & $38.0 \%$ & $9.8 \%$ & $20.9 \%$ & $.6 \%$ & 489 \\
\hline
\end{tabular}

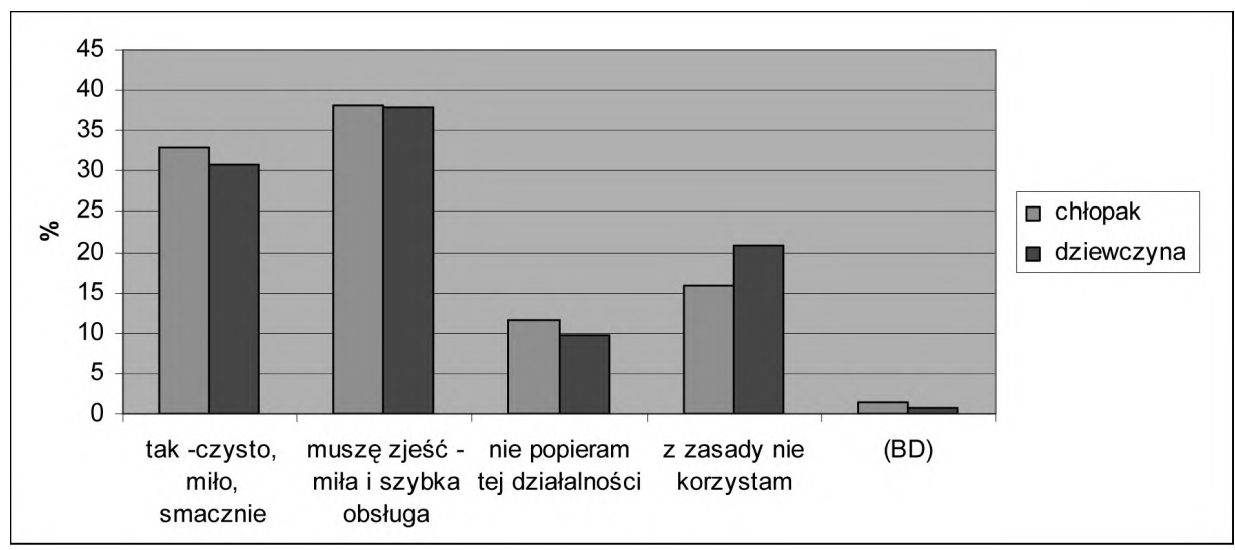


Dziewczęta optują za wyborem, który nie będzie miał skutków inwazyjnych dla zdrowia bądź środowiska. Wiedząc, że coś jest niewskazane, czy szkodliwe uwzględniają to chętniej w swoich codziennych wyborach. U chłopców widoczny jest wyraźniej czynnik estetyczny i konsumpcyjny.

\section{WALORY PRZY ZAKUPACH ART. SPOŻYWCZYCH}

\section{Czym się kierujesz przy zakupie artykułów spożywczych?}

\begin{tabular}{|c|c|c|c|c|c|c|}
\hline \#E11 & $x^{2}$ & Istotność & $\begin{array}{c}\text { smak, } \\
\text { estetyka, } \\
\text { latwość } \\
\text { pzygoto- } \\
\text { wania } \\
\%\end{array}$ & $\begin{array}{c}\text { skład, } \\
\text { wartość } \\
\text { odżyw- } \\
\text { cza, } \\
\text { zdrowie. } \\
\%\end{array}$ & $\begin{array}{c}\text { (BD) } \\
\% \\
\end{array}$ & $\begin{array}{c}\text { LICZBA } \\
\text { OSÓB }\end{array}$ \\
\hline OGÓŁEM & & & $54.3 \%$ & $44.3 \%$ & $1.4 \%$ & 849 \\
\hline PŁEĆ & 1.69233 & 0.19329 & & & & \\
\hline chłopak & & & $57.1 \%$ & $41.8 \%$ & $1.2 \%$ & 359 \\
\hline dziewczyna & & & $52.4 \%$ & $46.0 \%$ & $1.6 \%$ & 489 \\
\hline
\end{tabular}

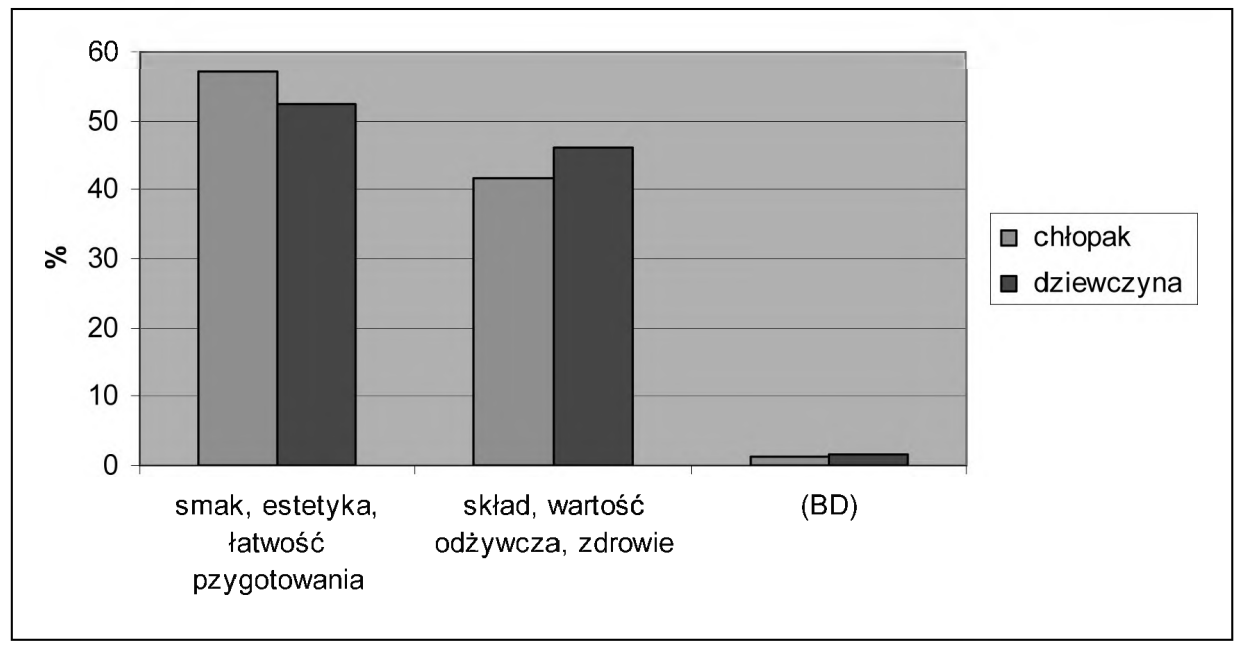

Dziewczęta we wszystkich swoich wyborach potwierdzają troskę o życie i zdrowie, opowiadając się za bezpośrednimi czynnikami gwarantującymi takie bezpieczeństwo. U chłopców zauważalna jest sprawa konsumpcji przy takich wyborach. 


\section{WYBÓR: ROWER - SAMOCHÓD}

Musisz pokonać dystans $5 \mathrm{~km}$. Masz do wyboru rower i samochód. Co robisz?

\begin{tabular}{|l|c|c|c|c|c|c|c|}
\hline \multicolumn{1}{|c|}{ \#E12 } & $\chi^{2}$ & Istotność & rower & $\begin{array}{c}\text { samo- } \\
\text { chód }\end{array}$ & to zależy. & (BD) & LICZBA \\
\hline OGÓŁEM & & & $25.9 \%$ & $22.1 \%$ & $50.6 \%$ & $1.3 \%$ & $\mathbf{8 4 9}$ \\
\hline PŁÉ́ & $\mathbf{2 9 . 2 2 3 0 9}$ & $\mathbf{0 . 0 0 0 0 0}$ & & & & & \\
chłopak & & & $23.7 \%$ & $30.9 \%$ & $43.2 \%$ & $2.2 \%$ & $\mathbf{3 5 9}$ \\
dziewczyna & & & $27.6 \%$ & $15.7 \%$ & $56.0 \%$ & $.6 \%$ & $\mathbf{4 8 9}$ \\
\hline
\end{tabular}

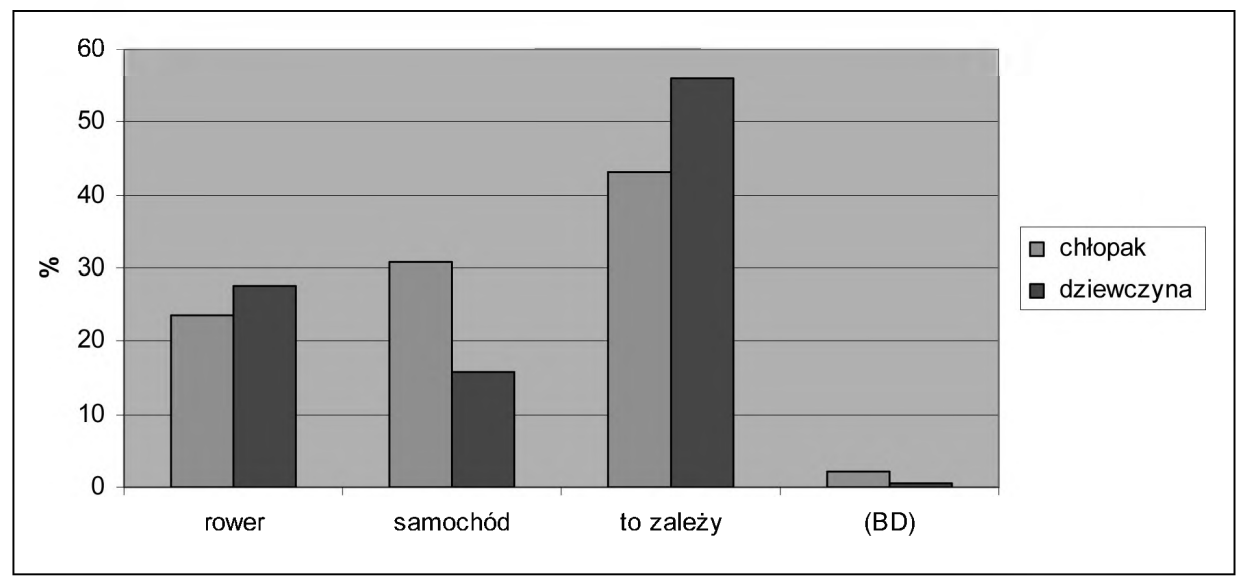

\utaj widać wyraźne zróżnicowanie między płciami. Chłopcy zdecydowanie wybierają samochód, który kojarzy się z większą wygodą i komfortem. Natomiast dziewczęta $\mathrm{w}$ większym stopniu deklarują wybór roweru, jako środka komunikacji bardziej przyjaznego otoczeniu. Warto jednak zwrócić uwagę na trzecią odpowiedź, która różnicuje najbardziej, a nie daje konkretnej odpowiedzi. 囚o już kolejna analogiczna sytuacja, w której dziewczęta wyraźniej wykazują większą elastyczność w dostosowaniu się do sytuacji.

\section{WYBÓR STYLU ŻYCIA}

Co współczesny człowiek powinien robić, aby prowadzić zdrowy styl życia. Odpowiedź, która jest najbliższa Twojej opinii zaznacz. Możesz wybrać dwie odpowiedzi 


\begin{tabular}{|l|c|c|c|c|c|c|c|c|}
\hline$\#$ & $\begin{array}{c}\text { wcielam } \\
\text { w życie } \\
\text { nowinki } \\
\text { medycz- } \\
\text { ne }\end{array}$ & $\begin{array}{c}\text { badania } \\
\text { profi- } \\
\text { laktycz- } \\
\text { ne }\end{array}$ & dieta & $\begin{array}{c}\text { dbanie } \\
\text { o wy- } \\
\text { gląd ze- } \\
\text { wnętrz- } \\
\text { ny, } \\
\text { kondy- } \\
\text { cję }\end{array}$ & $\begin{array}{c}\text { nie } \\
\text { zwra- } \\
\text { cam } \\
\text { uwagi } \\
\text { na nowe } \\
\text { teorie }\end{array}$ & $\begin{array}{c}\text { żyć } \\
\text { swoim } \\
\text { trybem. }\end{array}$ & (BD) & LICZBA \\
\hline OGÓŁEM & $12.0 \%$ & $27.4 \%$ & $17.4 \%$ & $49.0 \%$ & $10.0 \%$ & $45.0 \%$ & $37.8 \%$ & $\mathbf{8 4 9}$ \\
\hline PŁEĆ & $12.8 \%$ & $29.0 \%$ & $16.2 \%$ & $45.1 \%$ & $10.6 \%$ & $42.1 \%$ & $42.9 \%$ & 359 \\
chłopak & $11.5 \%$ & $26.4 \%$ & $18.2 \%$ & $51.7 \%$ & $9.6 \%$ & $47.2 \%$ & $33.5 \%$ & $\mathbf{4 8 9}$ \\
dziewczyna & & & & & & & & \\
\hline
\end{tabular}

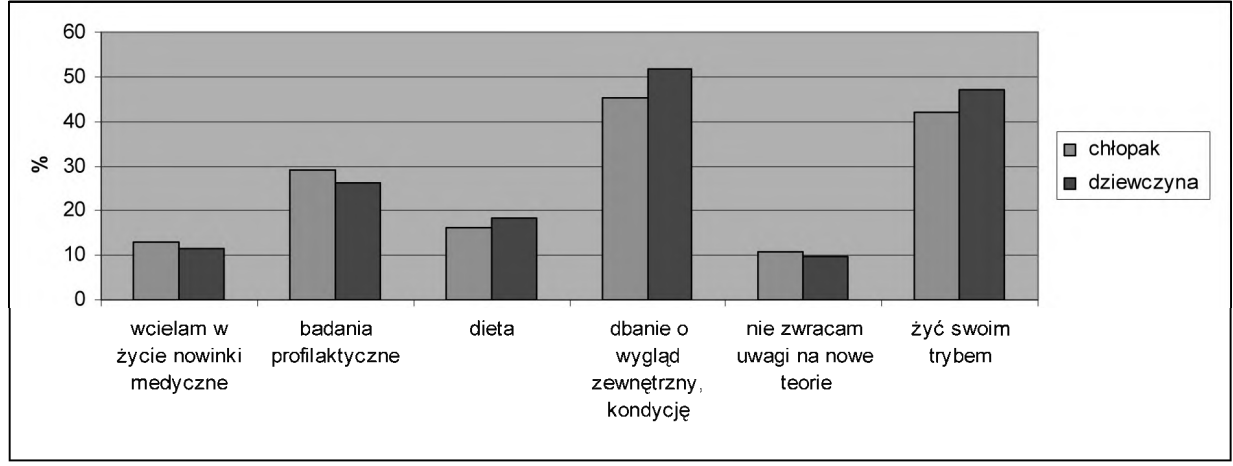

Dziewczęta sposób na zdrowy styl życia upatrują w dbaniu o siebie, przestrzeganiu diety, w wybraniu dla siebie odpowiedniego stylu życia. Chłopcy zaś liczą bardziej na umysły ludzkie (profilaktyka, medycyna).

\section{PRAWO DZIECKA POCZETEGO}

Jak myślisz, czy dziecko poczęte ma prawo do odpowiednio zachowanych norm ekologicznych, które $\mathrm{z}$ wymienionych uważasz za słuszne i niezbędne?

\begin{tabular}{|c|c|c|c|c|c|c|c|c|c|}
\hline \# & 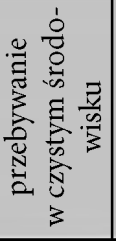 & 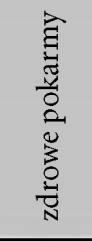 & 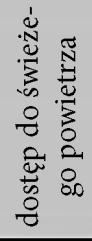 & 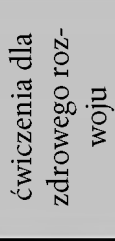 & 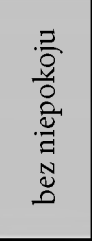 & 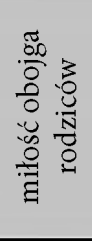 & 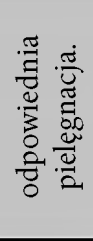 & $\widehat{\theta}$ & 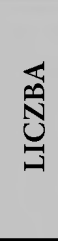 \\
\hline OGÓŁEM & $53.4 \%$ & $30.3 \%$ & $26.1 \%$ & $18.3 \%$ & $15.0 \%$ & $39.7 \%$ & $26.0 \%$ & $95.0 \%$ & 849 \\
\hline \multicolumn{10}{|l|}{ PEEĆ } \\
\hline chłopak & $50.4 \%$ & $28.1 \%$ & $26.2 \%$ & $17.8 \%$ & $15.3 \%$ & $34.8 \%$ & $25.1 \%$ & $94.7 \%$ & 359 \\
\hline dziewczyna & $55.4 \%$ & $31.9 \%$ & $26.2 \%$ & $18.6 \%$ & $14.7 \%$ & $43.1 \%$ & $26.6 \%$ & $95.3 \%$ & 489 \\
\hline
\end{tabular}




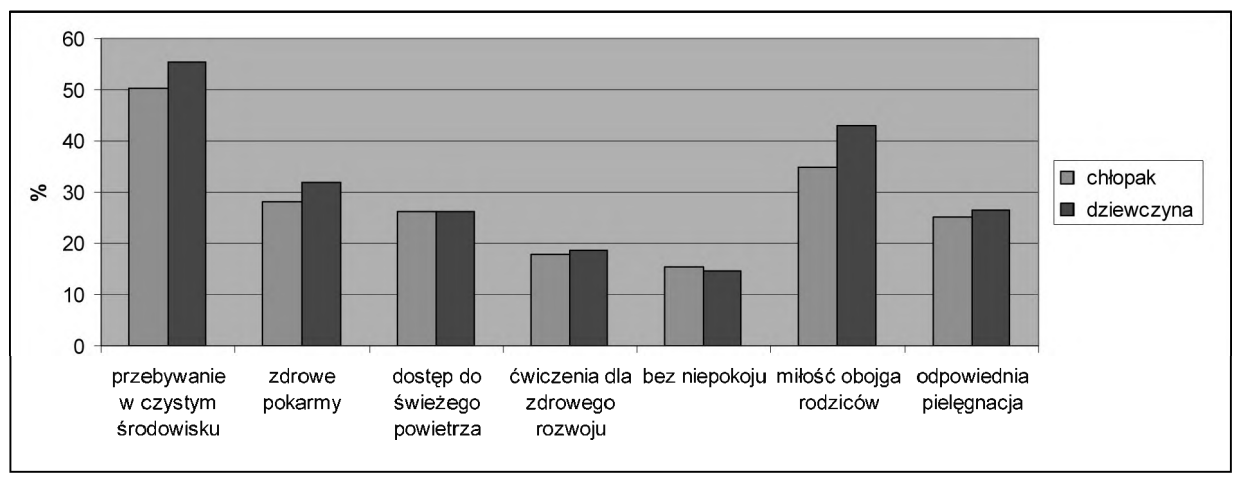

W tych odpowiedziach najbardziej różnicuje odpowiedź, w której chodzi o miłość obojga rodziców, ale największy procent młodzieży jako pierwszy czynnik prawa dziecka poczętego wymienili przebywanie w czystym środowisku. $\bigotimes \mathbf{a}$ odpowiedź też jest różnicowana przez płeć i dziewczęta stanowią tutaj przewagę. Jasno widać, po odpowiedziach na to pytanie, że dziewczęta wyraźniej widzą potrzebę zachowania czystego środowiska i łączą z tym jakość życia człowieka.

\section{ZAGROŻENIE}

Które z niżej wymienionych zagrożeń są dla Ciebie prawdziwymi niebezpieczeństwami?

\begin{tabular}{|l|c|c|c|c|c|c|}
\hline$\#$ & $\begin{array}{c}\text { zagłada } \\
\text { nuklearna }\end{array}$ & $\begin{array}{c}\text { ruina eko- } \\
\text { logiczna }\end{array}$ & $\begin{array}{c}\text { fanatyzm } \\
\text { rasowy }\end{array}$ & $\begin{array}{c}\text { akty } \\
\text { przemo- } \\
\text { cy. }\end{array}$ & (BD) & LICZBA \\
\hline OGÓŁEM & $53.6 \%$ & $44.2 \%$ & $29.0 \%$ & $44.8 \%$ & $85.1 \%$ & $\mathbf{8 4 9}$ \\
\hline PŁÉ́ & & & & & & \\
chłopak & $58.5 \%$ & $39.6 \%$ & $29.2 \%$ & $38.4 \%$ & $86.1 \%$ & $\mathbf{3 5 9}$ \\
dziewczyna & $49.9 \%$ & $47.4 \%$ & $28.6 \%$ & $49.3 \%$ & $84.7 \%$ & $\mathbf{4 8 9}$ \\
\hline
\end{tabular}




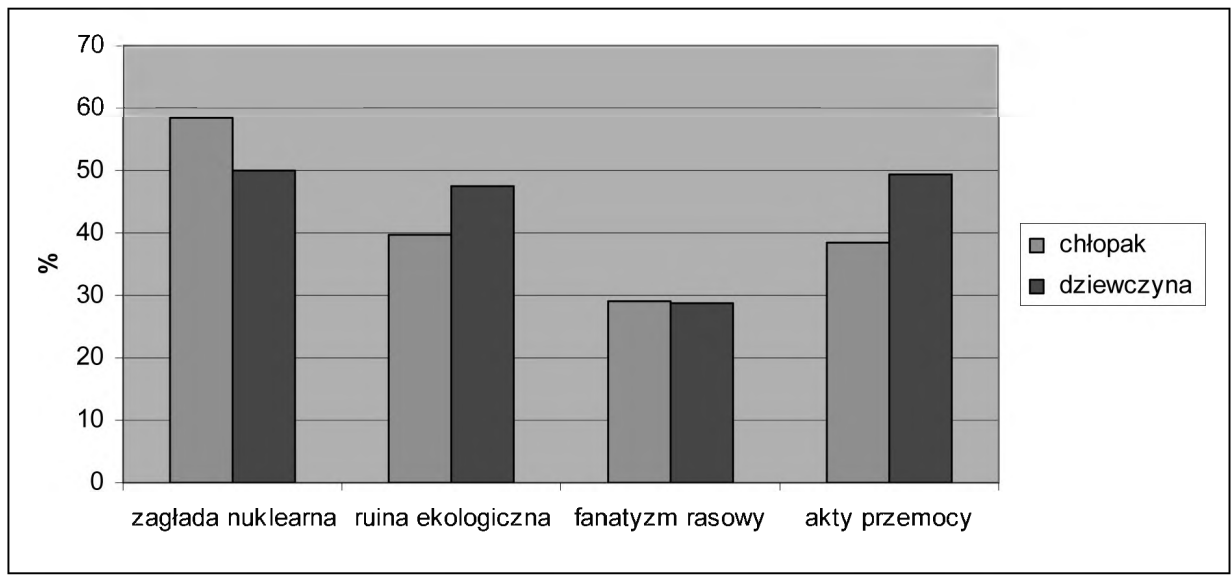

冈e odpowiedzi różnicują poglądy dziewcząt i chłopców. Dziewczęta bardziej boją się tego, co na dzień dzisiejszy wydaje się im realnym zagrożeniem. Akty przemocy, degradacja środowiska to doświadczenia naszego codziennego życia. Fanatyzm rasowy jako zagrożenie w podobny sposób widzą chłopcy jak i dziewczęta. Natomiast chłopcy jako największe zagrożenie traktują zagładę nuklearną. Może to być spowodowane lepszą orientacją techniczną, więcej wiedzą o możliwościach tej broni.

\section{SKUTKI NIESZANOWANIA ŻYCIA}

Czy zgadzasz się, że nie szanowanie cudzego i swojego życia objawia się (jeżeli zgadzasz się z którymś z powyższych stwierdzeń-zaznacz):

\begin{tabular}{|l|c|c|c|c|c|}
\hline$\#$ & $\begin{array}{c}\text { toksyko- } \\
\text { mania }\end{array}$ & $\begin{array}{c}\text { alkoho- } \\
\text { lizm }\end{array}$ & $\begin{array}{c}\text { beztro- } \\
\text { ska sek- } \\
\text { sualna. }\end{array}$ & (BD) & LICZBA \\
\hline OGÓŁEM & $38.9 \%$ & $51.4 \%$ & $29.3 \%$ & $86.7 \%$ & $\mathbf{8 4 9}$ \\
\hline PŁÉ́ & $41.2 \%$ & $51.8 \%$ & $33.4 \%$ & $85.0 \%$ & 359 \\
chłopak & $37.2 \%$ & $51.1 \%$ & $26.4 \%$ & $87.9 \%$ & $\mathbf{4 8 9}$ \\
dziewczyna &
\end{tabular}




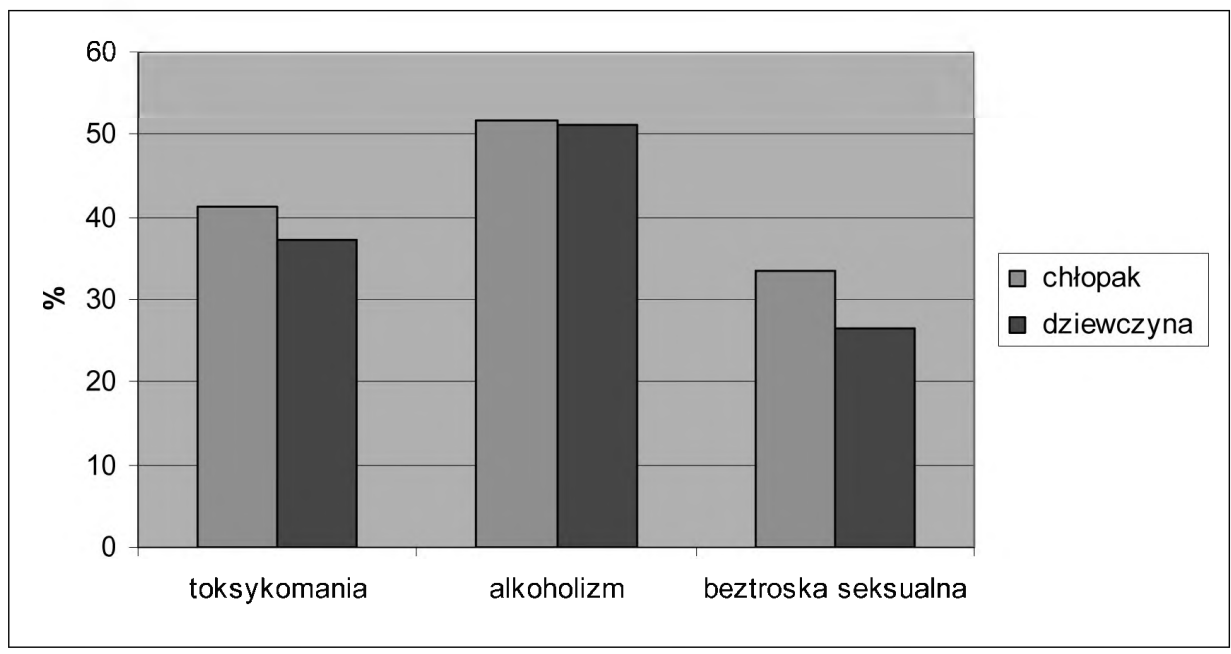

Odpowiedzi na te pytania wskazują, że świadomość zagrożeń życia spowodowanych używkami alkoholem i seksem jest duża. Wiemy, że to chłopcy chętniej sięgają po te rzeczy, dlatego też widać, że oni wykazują większą świadomość, może wynikającą z autopsji, że szacunek do życia może być niszczony, kiedy człowiek decyduje się na takie uzależnienia w życiu.

\section{PODSUMOWANIE}

Po przeanalizowaniu powyższych odpowiedzi można wyciągnąć kilka wniosków, które potwierdzą charakterystyczne zachowania dziewcząt dające się wytłumaczyć naukowo. Ankieta pomogła w badaniu świadomości ekologicznej i była pomocą w scharakteryzowaniu osobowości przetrwania. Uwzględniając odpowiedzi ze względu na rozróżnienie płci, można prześledzić różnice poglądów dotyczących spraw związanych z postrzeganiem i ochroną środowiska. Wyniki ankiety wyraźnie wskazują na zróżnicowane podejście do środowiska w zależności od płci. Kobiety wyraźniej widzą w środowisku przyrodniczym piękno, harmonię i ustalony porządek. Przyroda wzbudza w nich zachwyt i stanowi gwarancję życia.

Analizując badania ankietowe nie sposób nie zauważyć różnic w sposobie patrzenia na środowisko. Cytując za Estes możemy powiedzieć, że dojrzała kobieta (kobieta przetrwania) spoglądając na las widzi tam dom dla siebie i wszystkich ludzi, podczas, gdy inni często patrząc na ten sam las wyobrażają sobie, że wytną drzewa i zarobią na tym pieniądze $e^{4}$.

4 Clarissa Pinkola Estes, Biegnaca $z$ wilkami, s. 267. 
Czyste środowisko umożliwiające życie jest jak powietrze konieczne do życia - można oddychać pełną piersią tylko czystym powietrzem. Podobnie jest z psychiką kobiety, w której działa mechanizm pełnego oddechu i zmuszą ją do zaczerpnięcia świeżego powietrza.

Wyniki badań potwierdziły, że dziewczęta wykazują większą troskę o harmonijność i złożoność świata przyrody i że zdecydowanie przy każdej okazji stają się obrończyniami życia. W mniejszym stopniu niż chłopcy popierają rozwój techniczny i technologiczny, nie upatrują w nim panaceum na rozwiązanie problemów związanych z degradacją środowiska.

Jeżeli chcielibyśmy wyodrębnić typy osobowości prośrodowiskowej ze zróżnicowaniem na te charakterystyczne dla dziewcząt i te dla chłopców, to na podstawie badań ankietowych można przedstawić ${ }^{5}$ typ osobowości racjonalisty, naukowca myśliciela, technokraty i konsumpcjonisty, który przeważa w odpowiedziach chłopców i typ emocjonalny i estety przyrodnika, który charakteryzuje większą ilość dziewcząt.

Jeśli chodzi o szczególne zadanie kobiet w przygotowaniu osobowości środowiskowej, to kobieta może ukazać mężczyźnie jak zachwycać się przyrodą, jak rozwijać wrażliwość, jak otworzyć oczy na nowe perspektywy, których często autorem teoretycznych podstaw jest on sam. \o kobiety sercem czytają i wprowadzają w życie filozoficzne i teologiczne traktaty pisane przez mężczyzn.

Zadaniem kobiet jest aktywność związana z obroną mądrości duszy, aby nie uznawać nienormalnego stanu za normalny i aby mieć odwagę pielęgnować naturalne siły z jej elementami duszy i życia, które są bezcennym skarbem każdej kobiety.

Kiedy kobiety odmawiają sobie głosu w interweniowaniu w skandalicznych sprawach cichną jej racje, cichnie natura i świat przyrody. Cichnie miłość, chęć naprawiania świata, harmonia z naturą. Światu brakuje świeżego powietrza i wody, a także głosów świadomości.

Badania, które przeprowadziłam potwierdziły stawiane tezy i pozwalają na sprecyzowanie pożądanych cech osobowości, potrzebnych do kształtowania osobowości przetrwania.

5. GrochowsKa, Ekofilozoficzne uwarunkowania integralnego rozwoju czlowieka w ocenie mtodzieży, rozprawa doktorska napisana na Wydziale Filozofii Chrześcijańskiej UKSW, 2004, Warszawa, s. $180-185$.

Wyniki badań ankietowych wykorzystałam do skonstruowania 13 typów osobowości. Po przebadaniu statystycznym tylko $6 \mathrm{z}$ nich uzyskały interesującą istotność. \e typy osobowości przeanalizowałam $\mathrm{z}$ materiałem, który powstał w wyniku badan nad rolą kobiety w kształtowaniu człowieka przetrwania. 


\section{LI冈ERA囚URA}

Adhortacja apostolska Familiaris Consortio, Watykan 1982.

List apostolski Mulieris dignitatem, Watykan 1988.

List do rodzin, Watykan 1994.

Niewiasta i mężczyzna stworzyl ich. Odkupienie ciala odniesieniu do ludzkiej miłości. Zasadnicze cechy wychowania seksualnego, Rzym 1983.

PAPIESKA RADA DS. RODZINY, Ludzka plciowość: prawda i znaczenie. Wskazania dla wychowania w rodzinie, Watykan 1995.

Jan Pawła ll, O teologii ciała, KUL, Lublin 1982.

E. Pohorecka, Macierzyństwo w Życie Duchowe, nr 45/2006.

Benedykt XVI do uczestników kongresu z okazji 20-lecia Listu apostolskiego „Mulieris dignitatem"

Karina J. Zeno, Podróż kobiety, Warszawa, W drodze, 2007.

Osvaldo Poli, Serce taty niezbędnik każdego ojca, Warszawa, 2008, WAM.

Edyty Stein refleksje nad kobietą, przekład, J. Immakulata Adamska OCD, Małgorzata Grzywacz, 2005, Borne Sulimowo.

E. Stein, Chrześcijańskie życie kobiety.

\section{SUMMARY}

After analysing the above answers we can deduct some results, which confirm certain behaviour in girls that can be scientifically explained. A survey helped in establishing ecological consciousness and was a help in characterizing a survival persona. Looking at the answers with inclusion of two different sexes we can follow differences in the views concerning environmental protection. The survey results clearly show a difference in approach to the natural environment depending on the sex. Women more clearly see the beauty, harmony and set order in the environment. Nature astonishes them and is a guarantee of life. Analysing the survey results it is not possible not to see the differences in viewing the natural environment. Quoting Estes we can say that mature woman (surviving woman) looking at a forest sees a home for herself and other people, whilst others looking at the same forest imagine cutting down trees and making money on it.

Clean environment allowing life is like air necessary to live and you can only breathe deeply with clean air. It is similar with woman's psyche where a mechanism of full breath operates and forces her to breathe in the fresh air. The research results confirmed that girls show more concern about harmony and complexity of the natural world and definitely at every opportunity become protectors of life. \o a smaller extend that boys they support technological and technical development, they do not see it as a solution to problems connected with degradation of environment.

If you would like to separate pro environment personality types taking into account these characteristic for boys and girls, based on the performed survey, we can present: Rational type, scientific thinker and technocrat, consumer, which is dominant in boys answers and emotional type, esthetic environmentalist which is dominant within girls answers. Woman can show man how to admire nature, how to develop sensitivity and open ones eyes to new perspectives, whose theoretical author is often he himself. It is 
women who with their hearts read and introduce into life philosophical life and written theological works whose authors are men.

Woman's task is activity connected with protecting the wisdom of soul, not to accept abnormal state for normal and to hale the courage to celebrate natural forces with elements of Her soul and life, which a priceless treasure of each woman. When women do not follow their voice when intervening in unacceptable situations her views fade, her nature fades and natural world. Love fades as well as the will to repair the world and harmony with nature. The Word lacks fresh air and water, but also the voice of consciousness. Research I have performed confirmed the thesis I had made and allows to precise the desired personality characteristics, needed to shape a survival personality.

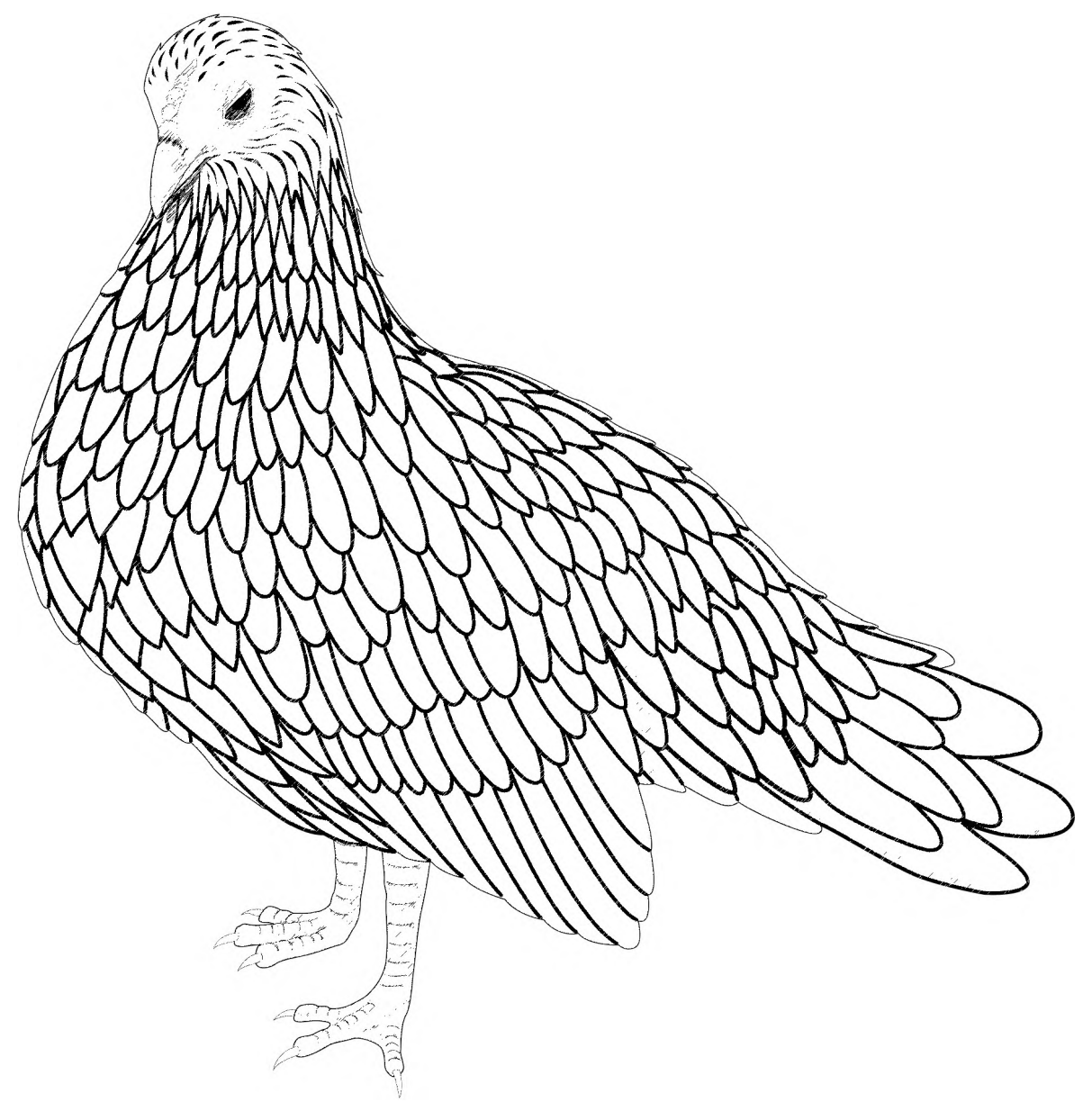

